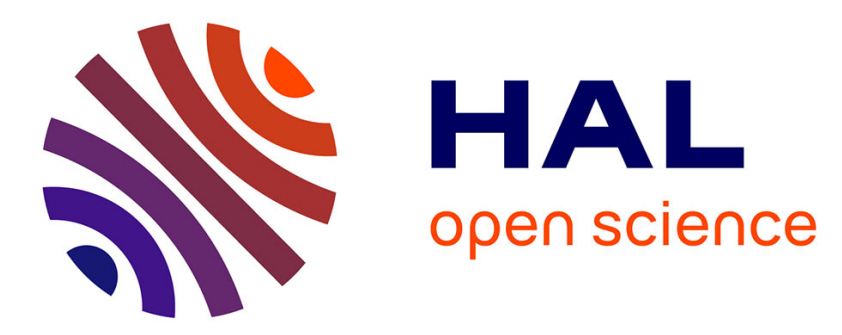

\title{
Feedbacks of soil properties on vegetation during the Green Sahara period
}

Weizhe Chen, Philippe Ciais, Dan Zhu, Agn Es Ducharne, Nicolas Viovy, Chunjing Qiu, Chunju Huang

\section{- To cite this version:}

Weizhe Chen, Philippe Ciais, Dan Zhu, Agn Es Ducharne, Nicolas Viovy, et al.. Feedbacks of soil properties on vegetation during the Green Sahara period. Quaternary Science Reviews, 2020, 240, pp.106389. 10.1016/j.quascirev.2020.106389 . hal-03065472

\section{HAL Id: hal-03065472 https://hal.science/hal-03065472}

Submitted on 4 Jan 2021

HAL is a multi-disciplinary open access archive for the deposit and dissemination of scientific research documents, whether they are published or not. The documents may come from teaching and research institutions in France or abroad, or from public or private research centers.
L'archive ouverte pluridisciplinaire HAL, est destinée au dépôt et à la diffusion de documents scientifiques de niveau recherche, publiés ou non, émanant des établissements d'enseignement et de recherche français ou étrangers, des laboratoires publics ou privés. 


\title{
Feedbacks of soil properties on vegetation during the Green Sahara period
}

\author{
Weizhe Chen ${ }^{\mathrm{a}, \mathrm{b}}$, Philippe Ciais ${ }^{\mathrm{b}}$, Dan Zhu ${ }^{\mathrm{b},{ }^{* *}}$, Agnès Ducharne ${ }^{\mathrm{c}}$, Nicolas Viovy ${ }^{\mathrm{b}}$, \\ Chunjing Qiu ${ }^{\mathrm{b}}$, Chunju Huang ${ }^{\mathrm{a}, *}$ \\ a State Key Laboratory of Biogeology and Environmental Geology, Hubei Key Laboratory of Critical Zone Evolution, School of Earth Sciences, China University \\ of Geosciences, Wuhan, 430074, China \\ ${ }^{\mathrm{b}}$ Laboratoire des Sciences du Climat et de l'Environnement, LSCE/IPSL, CEA-CNRS-UVSQ Université Paris-Saclay, Gif-sur-Yvette, 91191, France \\ ' Sorbonne Université, CNRS, EPHE, Milieux environnementaux, transferts et interaction dans les hydrosystèmes et les sols, Metis, 75005, Paris, France
}

\section{A R T I C L E I N F O}

\section{Article history:}

Received 29 December 2019

Received in revised form

20 May 2020

Accepted 24 May 2020

Available online $\mathrm{xxx}$

\section{Keywords:}

Dynamic global vegetation model (DGVM)

Mid-holocene

Soil organic carbon

Soil texture

Water infiltration

Bare soil evaporation

\begin{abstract}
A B S T R A C T
During the early to middle Holocene, the Sahara received enhanced precipitation and was covered by steppe-like vegetation with a large-scale hydrographic network of lakes, wetlands and fans, which is known as the Green Sahara (GS). However, most coupled land-atmosphere models underestimate the precipitation and vegetation cover, suggesting that critical atmospheric or land surface processes are lacking in those models. Climate-induced vegetation cover change can modify soil texture and physical properties over the long term, which in turn have feedbacks on vegetation. In this study, we examine five plausible soil-vegetation processes in a land surface model, which are expected to increase soil moisture for plants and possibly sustain equilibrium vegetation for a lower rainfall level. The annual precipitation required during the GS epoch to match the modelled vegetation distribution with paleorecords is inferred. Results demonstrate that these soil-vegetation processes have strong positive impacts on vegetation and soil moisture, especially the increase of soil evaporative resistance. After including all soil feedbacks on vegetation, the model requires only a mean precipitation of $\sim 400 \mathrm{~mm} / \mathrm{yr}$ to reproduce the pollen-inferred GS vegetation, instead of $\sim 600 \mathrm{~mm} / \mathrm{yr}$ when no soil feedback is included. From the midHolocene to pre-industrial period, we infer that terrestrial carbon stocks decrease by $\sim 58 \mathrm{PgC}$ due to the removal of carbon in vegetation, soil and litter pools of the GS. This work highlights the importance of soil-vegetation interactions for simulating dry-region vegetation coverage in models, and the impacts of natural land cover change on carbon budgets in the geological past.
\end{abstract}

๑) 2020 Elsevier Ltd. All rights reserved.

\section{Introduction}

During the early and mid-Holocene (11-5 ka), the Sahara received more rainfall than today and supported sparse vegetation, lakes and early human populations, which is referred to as Green Sahara (GS). This is confirmed by multiple paleorecords, including pollen-based reconstructions (Bartlein et al., 2010; Harrison, 2017), paleolake evidence (Lézine et al., 2011; Quade et al., 2018), leaf wax biomarkers preserved in marine sediment cores (Egerer et al., 2018; Tierney et al., 2017) and archaeological evidence (Brierley et al.,

\footnotetext{
** Corresponding author.

* Corresponding author.

E-mail addresses: zhudan.celia@gmail.com (D. Zhu), huangcj@cug.edu.cn (C. Huang).
}

2018; Drake et al., 2011). However, most state-of-the-art coupled climate-land models appear to underestimate the precipitation in that region and have difficulties in reproducing the vegetation cover of the mid-Holocene Sahara, suggesting missing critical processes in these models (Harrison et al., 2015).

Precipitation changes in Sahara are generally thought to be triggered by the orbital forcing, with the precession cycle as the primary driver. Increased summertime insolation of the Northern Hemisphere resulted in a northward migration of Intertropical Convergence Zone and rain belt (Adam et al., 2019). But Paleoclimate Modeling Intercomparison Project 3 (PMIP3) mid-Holocene (6 ka) simulations found that precession alone cannot explain the magnitude of rainfall changes, indicating that there are multiple positive amplifications (Harrison et al., 2015; Levis et al., 2004; Tierney et al., 2017). By using a coupled climate-vegetation model, Rachmayani et al. (2015) demonstrated that vegetation enhanced 
the summer precipitation in the Sahara-Sahel region by approximately $20 \%$, which was still not enough to reproduce reconstructed rainfall. A limited role of vegetation-rainfall feedbacks was also confirmed by other modeling studies (Braconnot et al., 2019; Pausata et al., 2016). Marine sediment records from African coast showed a large reduction in dust deposition during the midHolocene period (Egerer et al., 2018; McGee et al., 2013). The European Community Earth-System Model (EC-Earth) demonstrated that such a dust reduction drove an intensification of the Saharan heat low and enhanced the African monsoonal precipitation (Gaetani et al., 2017; Messori et al., 2018; Pausata et al., 2016). But Hopcroft and Valdes (2019) analyzed particle size range and concluded that only a limited enhancement of precipitation could be attributed to reduced dust during the mid-Holocene. The African rainfall response to dust aerosol effects is relatively low, and lower than the response to vegetation forcing (Thompson et al., 2019). Consequently, there must be omissions in models of known feedbacks that determine the vegetation-rainfall equilibrium. In this study, we argue that even though climate models may underestimate rainfall during the mid-Holocene, land surface processes alone can improve ecosystem water use and reproduce observed GS vegetation pattern with a lower rainfall requirement.

Soil properties are important factors impacting vegetation distribution and soil water turnover with respect to runoff and evapotranspiration losses. Soil water was found to be a dominant driver of ecosystem changes in present-day African drylands (Wei et al., 2019). During the Green Sahara period, the presence of steppe and woodland vegetation produced organic matter in soil and likely modified soil texture. Sedimentological records from Lake Yoa in northern Chad showed that the mid-Holocene soil contained larger soil organic carbon (SOC) and less sand percentage than today (Kropelin et al., 2008). SOC and plant roots significantly modify soil hydraulic properties and consequently modify productivity, water use and vegetation structure (Lawrence and Slater, 2007; Morris et al., 2015). For example, Tafasca et al. (2019) found that medium soil textures give the highest evapotranspiration and lowest total runoff rates by prescribing different texture maps in the ORCHIDEE (Organizing Carbon and Hydrology In Dynamic Ecosystems) land surface model. In addition, plant roots prominently increase the soil water conductivity by increasing infiltration under vegetation by a factor of up to four compared to bare soil (Lyford and Qashu, 1969), and improve plant water use. Besides, many studies have revealed the overestimate of bare soil evaporation and the underestimated proportion of transpiration in current land surface models (Oleson et al., 2008), which may partially explain a failure of these models to reproduce the GS (Braconnot et al., 2019; Hopcroft and Valdes, 2019). Thus, a better formulation of soil hydraulic processes (e.g. soil hydric stress, bare soil evaporation and plant root induced infiltration changes) is essential in dynamic global vegetation models (DGVMs) for simulating the vegetation which was prevailed during the GS epoch.

Here we address the question of precipitation and equilibrium vegetation reconstruction in the mid-Holocene GS. This question is tackled using a new land surface model with a dynamic vegetation module and a more complete representation of soil-hydraulic processes than previous models applied for the GS-enigma. The land surface model tool used is ORCHIDEE-MICT (ORganizing Carbon and Hydrology in Dynamic EcosystEms-aMeliorated Interactions between Carbon and Temperature) (Guimberteau et al., 2018), a version of the ORCHIDEE land surface model that includes the following important processes in dry regions: positive dependence of water holding capacity on soil carbon, improved formulation of soil evaporation resistance, dynamic water uptake by roots in the soil profile, and a calibrated dynamic vegetation model. In details, the aim of this work is to determine the annual precipitation required to sustain a vegetation distribution consistent with available paleo-evidence when including key soilvegetation feedbacks in the ORCHIDEE-MICT model, and compare this precipitation estimate to the value required without feedbacks. Furthermore, we want to explore the impact of each soil process on vegetation dynamics and terrestrial water budgets. With a better vegetation reconstruction in the DGVM model, it is possible to estimate the terrestrial carbon stocks in the GS.

\section{Materials and methods}

\subsection{ORCHIDEE-MICT land surface model}

The ORCHIDEE-MICT is a process-based dynamic global vegetation model (DGVM) that simulates carbon, water and energy fluxes with the atmosphere and carbon and water pools dynamics within ecosystems (Guimberteau et al., 2018). The vegetation dynamics module of the model mainly follows on Krinner et al. (2005). The model defines vegetation types as 13 plant functional types (PFTs) based on morphology, leaf type, phenology, photosynthetic pathway and climatic regions. PFTs go through the same suite of processes (photosynthesis, phenology, allocation of carbon assimilates to plant biomass compartments, carbon flow from living biomass to litter pools after senescence and/or mortality, from litter to soil carbon pools, and heterotrophic respiration), but with PFT-specific parameter values. The vegetation distribution is simulated dynamically through bioclimatic limits, competition between grasses and trees based on the maximum space occupied by trees, and climate dependent tree and grass mortality processes (Zhu et al., 2015). The process-based fire module SPITFIRE (SPread and InTensity of FIRE) (Thonicke et al., 2010; Yue et al., 2014) was included in all simulations because fire interactions with vegetation in tropical dry-lands is non-negligible (Chen et al., 2019a; Pugh et al., 2019).

Five different soil hydrological model settings are tested in this study. First, we tested the effect of a finer texture, assuming that vegetation during the long period of GS transformed the soils to a finer texture than the current sandy soils of Sahara. Finer soil texture has a higher field capacity and wilting point but a lower hydraulic conductivity (Text S1). Second, the presence of SOC significantly increases soil porosity and therefore available water capacity (Guimberteau et al., 2018; Lawrence and Slater, 2007). Third, the parameterization of optimal water utilization by plant roots along the soil profile (Beer et al., 2007), called Droot for dynamic root uptake, should enhance productivity and vegetation coverage in dry-lands. Fourth, a higher vegetation cover increases root density, which in turn increases soil water infiltration and possibly allows more water in deep soil layer for plants, called Kroot process (d'Orgeval et al., 2008). Fifth, the presence of vegetation and litter on the ground increases the soil resistance to reduce bare soil evaporation, a flux which is generally overestimated in current land surface model (Oleson et al., 2008; Sellers et al., 1992). The model test with a higher soil resistance is called Rsoil. Related hydraulic equations and parameters from Van Genuchten (1980) are descried in Text S1. Separately or combined, ignoring these processes possibly leads to underestimate the productivity and coverage of vegetation during the GS period, a common source of bias of land models and land-atmosphere models (Braconnot et al., 2019).

\subsection{Climate forcing and simulations design}

The monthly climate forcing variables were extracted from Institut Pierre-Simon Laplace Coupled Ocean-Atmosphere General Circulation Model simulation for the fifth IPCC report 
(IPSL_CM5A_LR) at a spatial resolution of $1.875^{\circ} \times 3.75^{\circ}$ (Kageyama et al., 2013). General circulation models have inevitable precipitation and temperature bias in their simulations (Aloysius et al., 2016), including ancient climate (Harrison et al., 2015). This bias may cause an incorrect vegetation distribution to be simulated by land surface models. Hence, the climate bias correction from O'Ishi and Abe-Ouchi (2013) was applied to derive six-hourly mid-Holocene climate. In details, the monthly difference between the midHolocene and pre-industrial experiments by IPSL_CM5A_LR was added to the pre-industrial CRUNCEP v5 (Climatic Research UnitNational Centers for Environmental Prediction) observation-based gridded climate fields (Wei et al., 2014). The six-hourly CRUNCEP data between 1901 and 1910 were taken as the pre-industrial climate forcing for the ORCHIDEE-MICT. Because available IPSL_CM5A_LR outputs were monthly, we used the bias corrected sixhourly mid-Holocene climate to drive ORCHIDEE-MICT which requires high frequency forcing.

In those bias corrected mid-Holocene climate forcing fields, precipitation (P0) over the Sahara is less than $50 \mathrm{~mm} / \mathrm{yr}$, coarsely underestimated compared to paleo-evidence (Bartlein et al., 2010; Wu et al., 2007). Thus, we tested an increasing range of precipitation level by adding $200 \mathrm{~mm} / \mathrm{yr}$ (P200), $400 \mathrm{~mm} / \mathrm{yr}$ (P400) or $600 \mathrm{~mm} / \mathrm{yr}$ (P600) to P0 (Fig. 1). To do so, the six-hourly precipitation at the $12^{\circ} \mathrm{N}$ latitudinal band in P0 was selected, and each rainfall event of each grid cell was multiplied by a scaling factor to reach the MAP level targeted (Fig. S1). This six-hourly forcing was then added over all the grid cells in the Sahara latitude band between $18^{\circ} \mathrm{N}$ and $32^{\circ} \mathrm{N}$. Because P0 has a very low rain frequency over Sahara, it would be unreasonable to add 200-600 mm directly to this forcing, as it would result in all annual rain falling in few days a year. This is the reason why we assumed the seasonality of the band $12^{\circ} \mathrm{N}$ to prevail over the whole Sahara during the Mid-Holocene.

The ORCHIDEE-MICT simulations were forced with a fixed atmospheric $\mathrm{CO}_{2}$ concentration of 264 ppm (Elsig et al., 2009) in the mid-Holocene runs. To decouple the effect of the five soil settings, seven sensitivity experiments were performed for each of the four precipitation forcings (Table 1 ). In the reference simulation (Exp_CTL), input soil texture map is set as present-day observation (Fig. 2) from ISRIC (International Soil Reference and Information Centre) soil products (Hengl et al., 2017). In Exp_TEX, we hypothesized that soil texture was loamier in the mid-Holocene Sahara and similar to present Sahel vegetated area where silt loam dominates. Silt loam was thus prescribed through replacing sand in ISRIC map. The five other experiments activate each single process, SOC (Exp_SOC), Droot (Exp_DRT), Kroot (Exp_KRT), Rsoil (Exp_RSL)

(a) Mean annual precipitation ( $\mathrm{P} 400)$

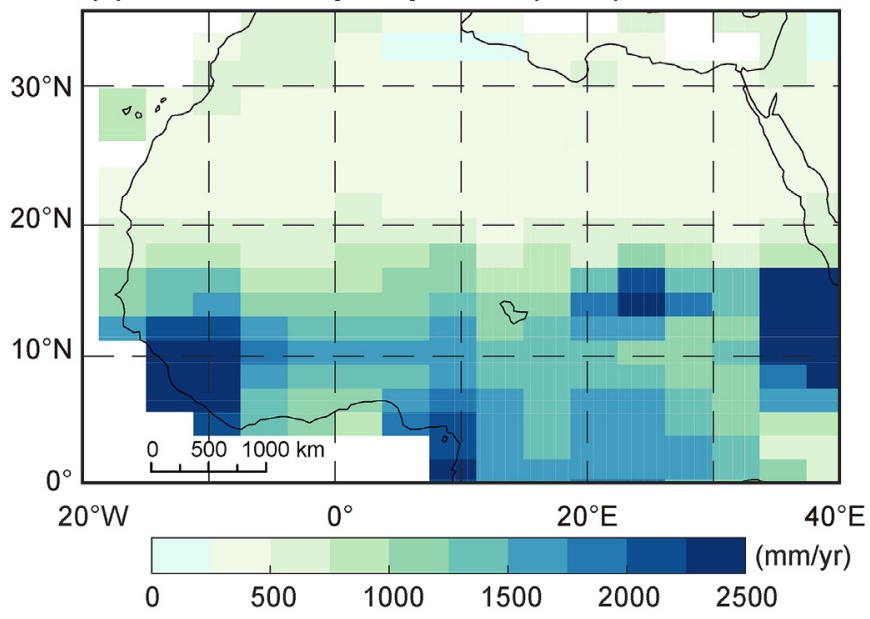

(b) Mean annual temperature

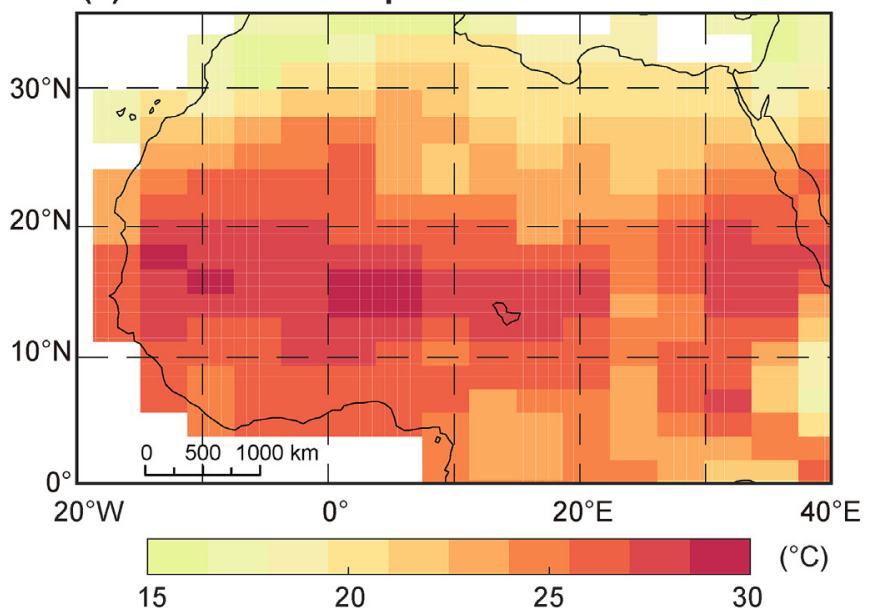

(c) Latitudinal precipitation

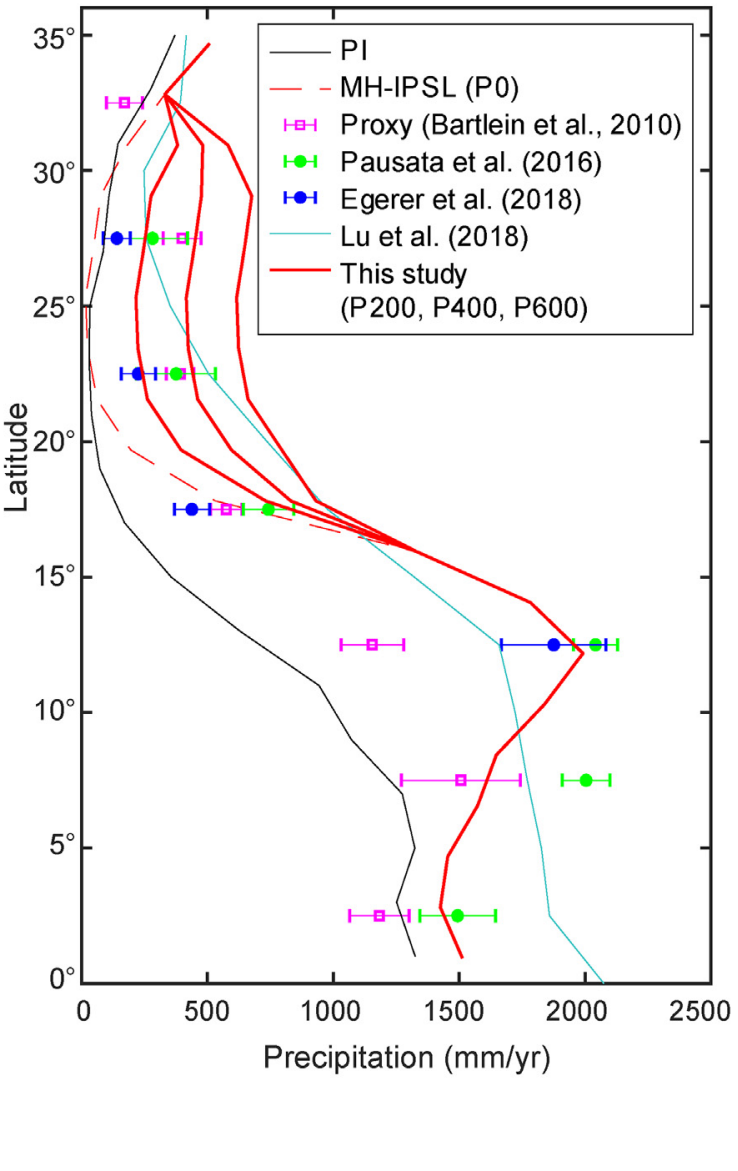

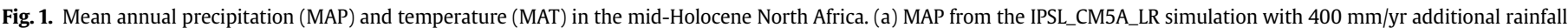

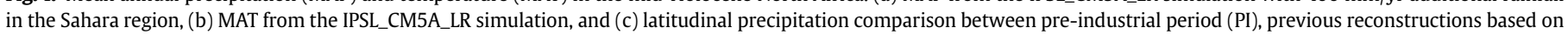
proxy or models (Bartlein et al., 2010; Egerer et al., 2018; Lu et al., 2018; Pausata et al., 2016) and precipitation tested in this study. 
Table 1

Summary of the experiments used in this study.

\begin{tabular}{llllll}
\hline Name & Soil texture & SOC & Droot & Kroot & Rsoil \\
\hline Exp_CTL & Sand & Off & Off & Off & Off \\
Exp_TEX & Silt Loam & Off & Off & Off & Off \\
Exp_SOC & Sand & On & Off & Off & Off \\
Exp_DRT & Sand & Off & On & Off & Off \\
Exp_KRT & Sand & Off & Off & On & Off \\
Exp_RSL & Sand & Off & Off & Off & On \\
Exp_ALL & Silt Loam & On & On & On & On \\
\hline
\end{tabular}

The seven sensitivity experiments were performed for each of the four precipitation forcings, P0, P200, P400 and P600. "Sand" means using soil texture input as today (Fig. 2). "Silt Loam" means changing sand in the soil map to silt loam.

(a) ISRIC soil texture map

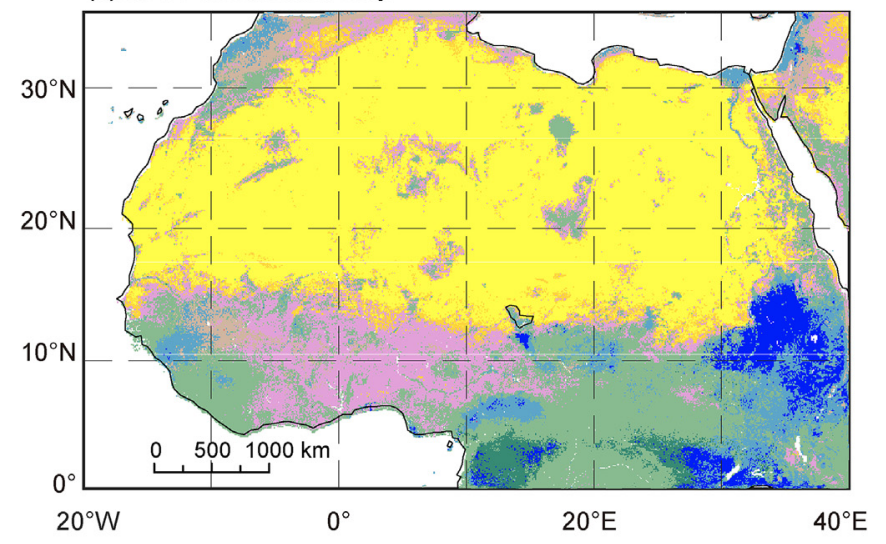

(b) USDA soil texture triangle

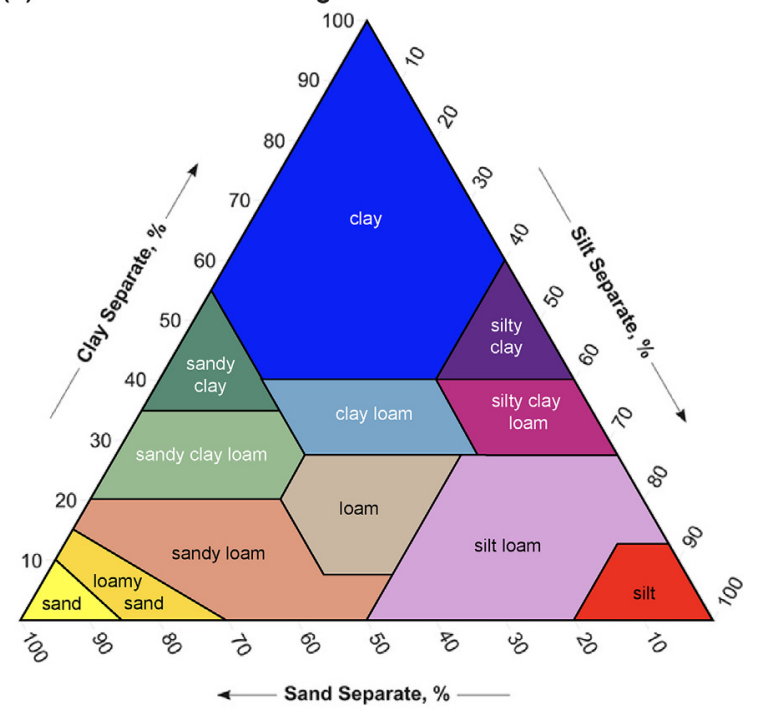

Fig. 2. Present soil texture classes in the studied regions. (a) Soil texture map from ISRIC soil products (Hengl et al., 2017), and (b) soil texture triangle of the 12 textural classes as defined by the United States Department of Agriculture (USDA).

or all the five factors together (Exp_ALL). Each experiment was run for a 100 -year spin-up to reach quasi-equilibrium for vegetation productivity and cover, followed by 20,000-year soil carbon submodel simulation and 30-year full model simulation again. The vegetation dynamic module and fire disturbance were activated to let different vegetation types grow to equilibrium from bare soil, using the DGVM calibration for tropical regions described by Chen et al. (2019a). Then, the average results from the last ten simulation years were analyzed. In the PI simulation, input soil texture map was prescribed as today and other four soil factors were activated and atmospheric $\mathrm{CO}_{2}$ concentration was fixed at $285 \mathrm{ppm}$.

\subsection{Converting vegetation types into mega-biomes}

The Global Palaeovegetation Mapping Project (BIOME 6000) reconstructed a global map of biomes at $6 \mathrm{ka}$ (Prentice et al., 1996), which is here compared with the modelled vegetation distribution through the ORCHIDEE-MICT. The BIOME 6000 data have been widely used for evaluation of model experiments (Dallmeyer et al., 2019; Lu et al., 2019). The BIOME 6000 reconstructions regrouped 34 types of reconstructed ecosystems based on palaeoecological (pollen and plant macrofossil) records into nine mega-biomes on the basis of their structure and functioning (Harrison, 2017; Harrison et al., 2015). In North Africa, there are 5 types of megabiomes: tropical forest, warm-temperate forest, savannah and dry woodland, grassland and dry shrubland, and desert. The northern limit of tree line (i.e. savannah and dry woodland) from the BIOME 6000 data is $15^{\circ} \mathrm{N}$ both at $0 \mathrm{ka}$ and $6 \mathrm{ka}$. It is different from previous studies showing that tree line in the mid-Holocene North Africa shifted northward to $20^{\circ} \mathrm{N}$ (Egerer et al., 2018; Hély et al., 2014; Kropelin et al., 2008; Larrasoana et al., 2013). Therefore, we revised the mega-biome regrouping method by assigning the biome "xerophytic woods/scrub" to savannah and dry woodland megabiome rather than grassland and dry shrubland.

In this study, the DGVM simulates vegetation distribution with a maximum of 11 types of natural PFTs. But three boreal types of these 11 PFTs do not exist in the study area because of the warm climate. The modelled PFTs were regrouped into five mega-biomes using the algorithm described by Prentice et al. (2011). The assignment method depends on modelled total foliage projective cover and tree height to distinguish desert, grassland, savannah and forest (Fig. 3). And the dominant woody PFT (i.e. tropical tree PFT or temperate tree PFT) was used to identify forest type.

\subsection{Water stress and water use indicators}

We analyzed the model output of net primary production (NPP), evaporation, transpiration, soil moisture (SM), surface runoff (Qs), deep drainage (Qd), soil relative humidity (RH) and rain-use efficiency (RUE). The RH and RUE are indicators that represent water constraints on vegetation. The soil RH is defined as:

$R H=\frac{\theta-\theta_{w}}{\theta_{c}-\theta_{w}}$

where $\theta, \theta_{c}$ and $\theta_{w}$ are simulated volumetric water content $\left(\mathrm{m}^{3} / \mathrm{m}^{3}\right)$ for the surface $2-\mathrm{m}$ soil, water content $\left(\mathrm{m}^{3} / \mathrm{m}^{3}\right)$ at field capacity and wilting point for vegetation, respectively. $\mathrm{RH}$ is directly used in the

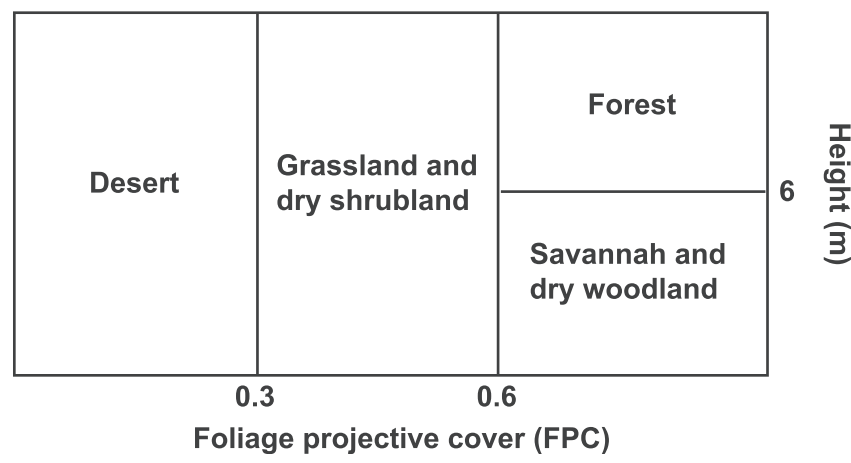

Fig. 3. Algorithm to convert the modelled PFT into mega-biomes in North Africa. 
model (for each soil layer) to parameterize water stress on stomatal conductance and photosynthetic rates, when $\mathrm{RH}$ goes below a PFT specific threshold during a model time step (Krinner et al., 2005). The RUE quantifies an ecosystem's ability to use rainfall, which is defined following Kaptue et al. (2015):

$R U E=\frac{N P P}{M A P}$

where NPP and MAP are averaged over the last ten simulation years.

\section{Results}

\subsection{Model evaluation}

The performance of the ORCHIDEE-MICT model has been extensively evaluated under present climate, mostly in the northern hemisphere (Guimberteau et al., 2018). The model was applied in paleoecology studies to reconstruct global vegetation distribution under Last Glacial Maximum climate ( $21 \mathrm{ka}$ ) (Chen et al., 2019a; Zhu et al., 2018). Here we evaluate the performance of the model to simulate the vegetation and productivity during the preindustrial period (PI) in the North Africa.

The modelled mega-biome distribution in PI climate is compared against BIOME 6000 dataset, which mapped vegetation patterns using fossil pollen and plant-macrofossil data from individual sites at 0 ka (Harrison, 2017; Harrison et al., 2015). The pollen-inferred vegetation distribution for the PI period is generally well captured by the model in the North Africa (Fig. 4a). The vegetation extension is zonal, corresponding to the precipitation pattern. Specifically, records and simulations consistently show the northern boundaries of forest, woodland and grassland at $12^{\circ} \mathrm{N}$, $16^{\circ} \mathrm{N}$ and $20^{\circ} \mathrm{N}$, respectively. And the northern coast of Africa is dominated by warm-temperate forest and grassland. But the model could not reproduce the warm-temperate forest in the eastern Africa equatorial region where multiple biomes coexist, likely because of the low spatial resolution of the forcing or inaccurate correspondence between PFTs and mega-biomes. The spatial patterns of present-day soil texture and biome type exhibit a good correspondence (Figs. 2 and 4), implying strong interactions between soil texture and vegetation.

Site-level observational vegetation productivity has a strong positive relationship with MAP across different biomes (Kaptue et al., 2015; Michaletz et al., 2014). We performed a simulation PI385, with PI climate conditions and all soil settings activated but $\mathrm{CO}_{2}$ prescribed as $385 \mathrm{ppm}$ instead of $285 \mathrm{ppm}$ (Fig. 5). The PI385 simulation is designed to evaluate modelled NPP and RUE against current observations affected by present-levels of $\mathrm{CO}_{2}$ (Liu et al.,

\section{(a) PI simulation}

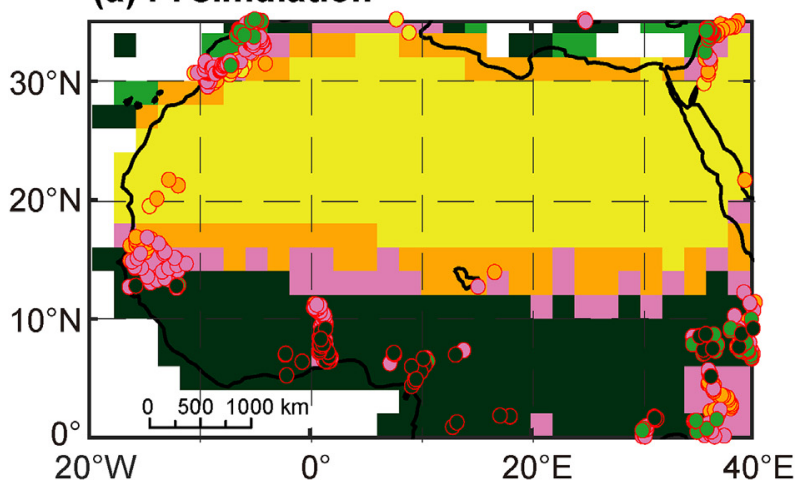

(c) P400_CTL simulation

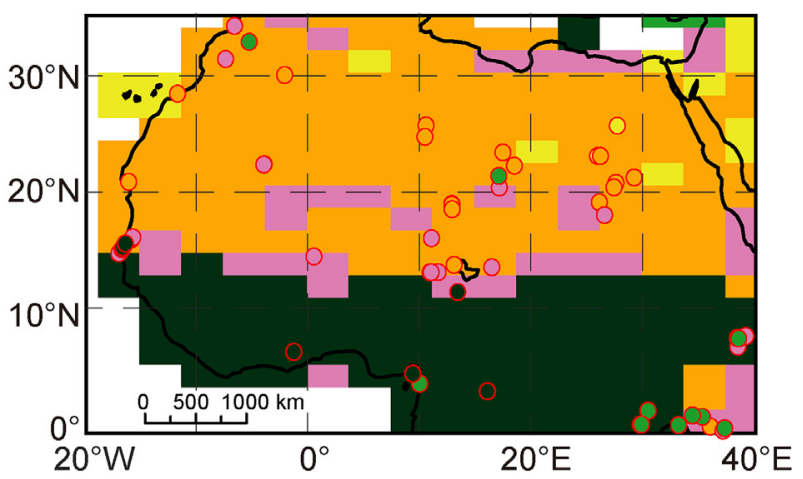

(b) PO_CTL simulation

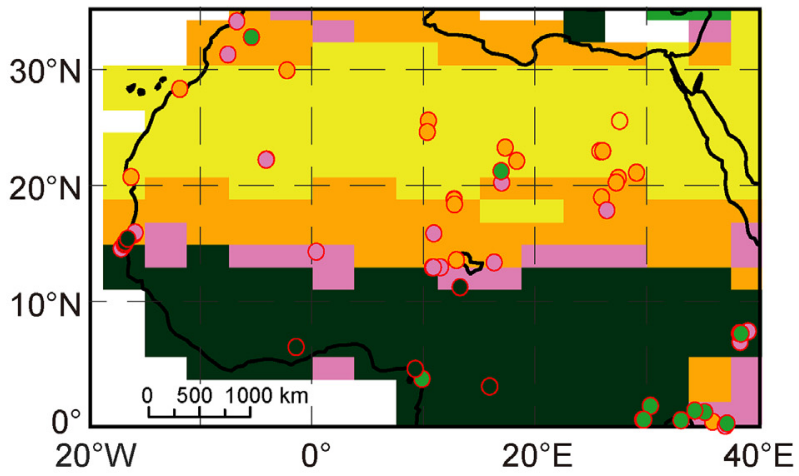

(d) P400_ALL simulation

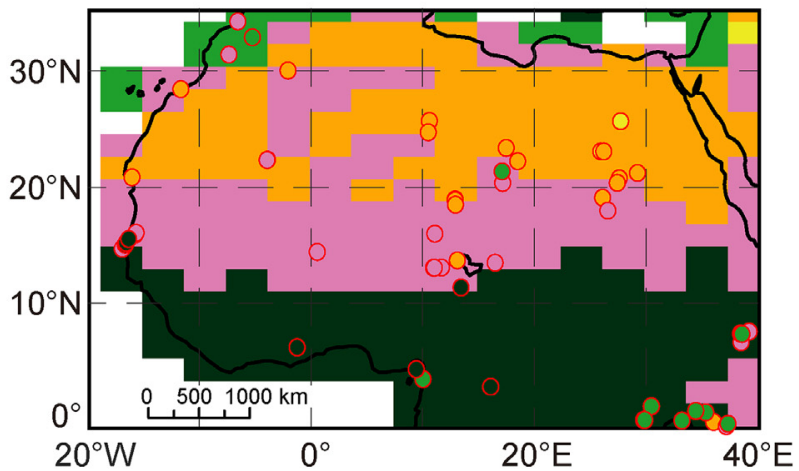

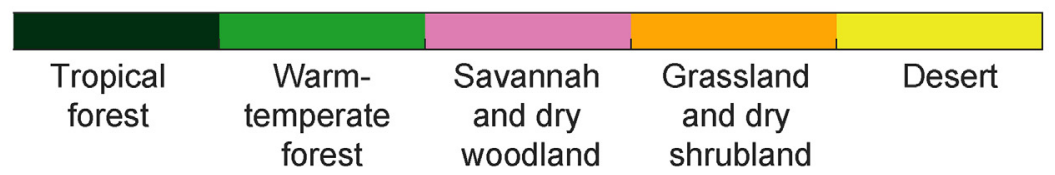

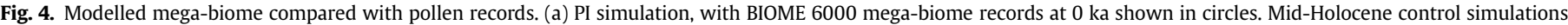

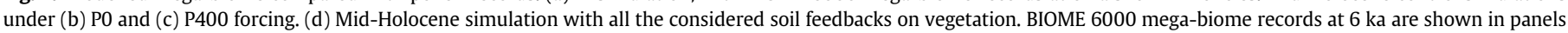

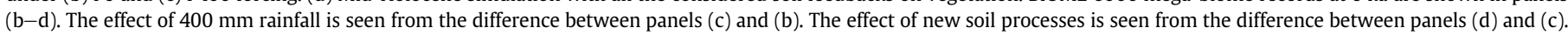



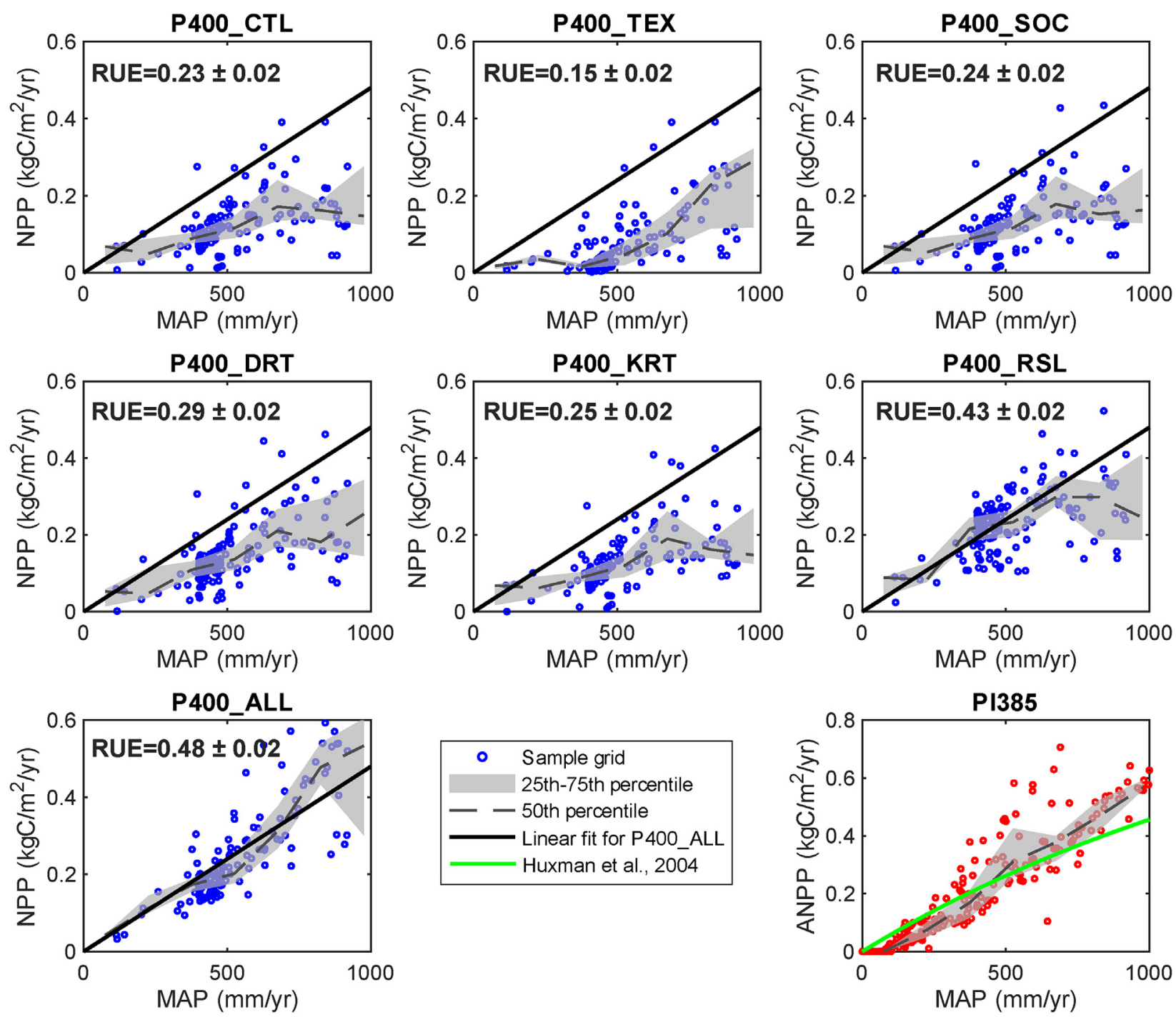

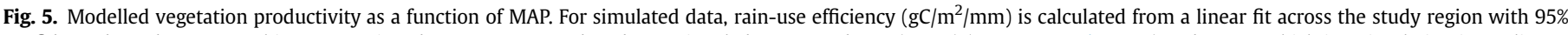

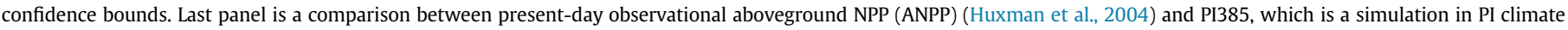
with all soil factors activated while $\mathrm{CO}_{2}$ is set as $385 \mathrm{ppm}$.

2019), excluding human land use impacts. Within the MAP gradient between 0 and $1000 \mathrm{~mm} / \mathrm{yr}$, modelled aboveground NPP (ANPP) in the PI385 simulation increases with MAP and this relationship follows the present-day ANPP-MAP curve derived by Huxman et al. (2004) from long-term ecological measurements. In the midHolocene simulation with all soil settings being activated, the RUE is of $0.48 \pm 0.02 \mathrm{gC} / \mathrm{m}^{2} / \mathrm{mm}$. But in the CTL simulation or any simulation with a single soil setting modified, RUE is underestimated, ranging from 0.15 to $0.43 \mathrm{gC} / \mathrm{m}^{2} / \mathrm{mm}$. This result indicates that it is essential to consider soil processes to simulate vegetation productivity as a function of MAP correctly.

\subsection{Vegetation distribution in the mid-Holocene North Africa}

In the mid-Holocene, the impacts of precipitation and soil processes on vegetation cover are further analyzed by seven sensitivity experiments for four precipitation levels described above (Table 1). The modelled mid-Holocene vegetation distribution in North Africa is compared with BIOME 6000 reconstruction at $6 \mathrm{ka}$ in Fig. 4. Increased precipitation by $400 \mathrm{~mm} / \mathrm{yr}$ in the Sahara leads to a land cover shift from desert to grassland between $20^{\circ} \mathrm{N}$ and $30^{\circ} \mathrm{N}$
(Fig. 4b and c). Further, including all soil processes makes the savannah and dry woodland extend northward and replace grasslands between $12^{\circ} \mathrm{N}$ and $20^{\circ} \mathrm{N}$ (Fig. 4c and d). With enhanced precipitation by $400 \mathrm{~mm} / \mathrm{yr}$ and all soil processes (i.e. P400_ALL), the modelled woody extension at $20^{\circ} \mathrm{N}$ is comparable to BIOME 6000 dataset and previous reconstructions based on pollen fossil sample at 6 ka (Hély et al., 2014; Kropelin et al., 2008; Larrasoana et al., 2013), as shown in Fig. 4d. The inclusion of soil feedbacks transforms the grassland and dry shrubland to warm-temperate forest in Morocco and the Mediterranean region, consistent with paleorecords. In contrast, P200_ALL still produces an area of desert while P600_ALL overestimates the coverage of savannah (Fig. 6). Regionally, a MAP of $400-500 \mathrm{~mm} / \mathrm{yr}$ at $28^{\circ} \mathrm{N}$ in P400_ALL simulation produces patches of Savannah, where grassland is suggested from pollen data, indicating a slight overestimate. Thus, a MAP of $\sim 400 \mathrm{~mm} / \mathrm{yr}$ over $18^{\circ} \mathrm{N}-32^{\circ} \mathrm{N}$ is sufficient for the ORCHIDEE-MICT model to reproduce the GS biome distribution if all soil processes are included.

These soil processes differ in their impact on vegetation distribution (Fig. 6). Finer soil texture (Exp_TEX) leads to more desert in Sahara but a slight expansion of woody biomes in the semi-humid 
PO
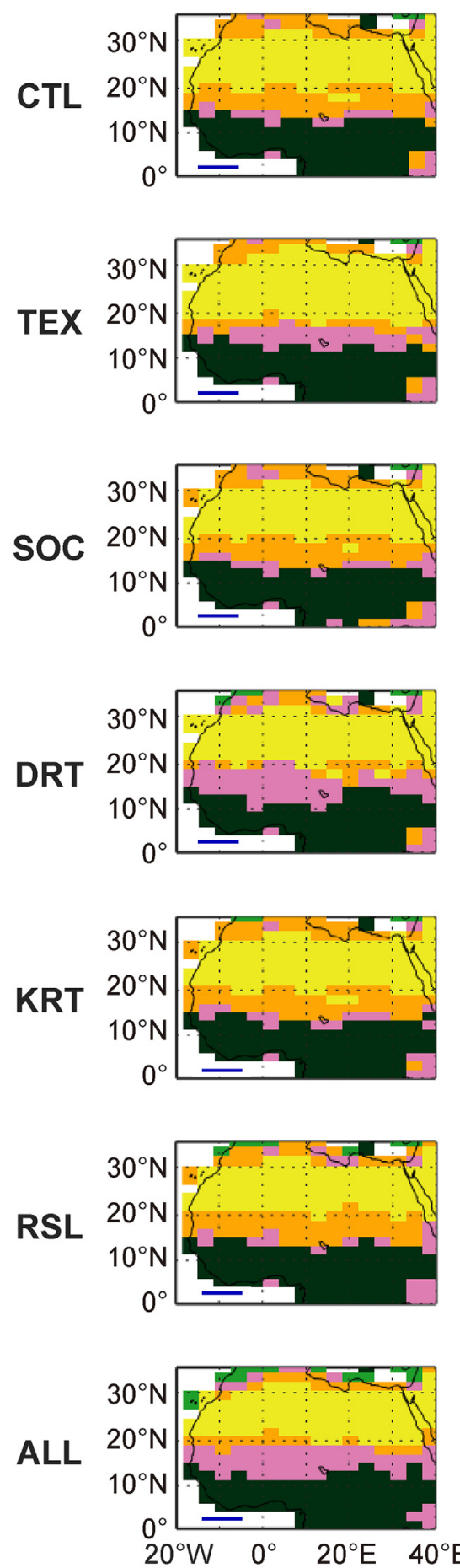

P200
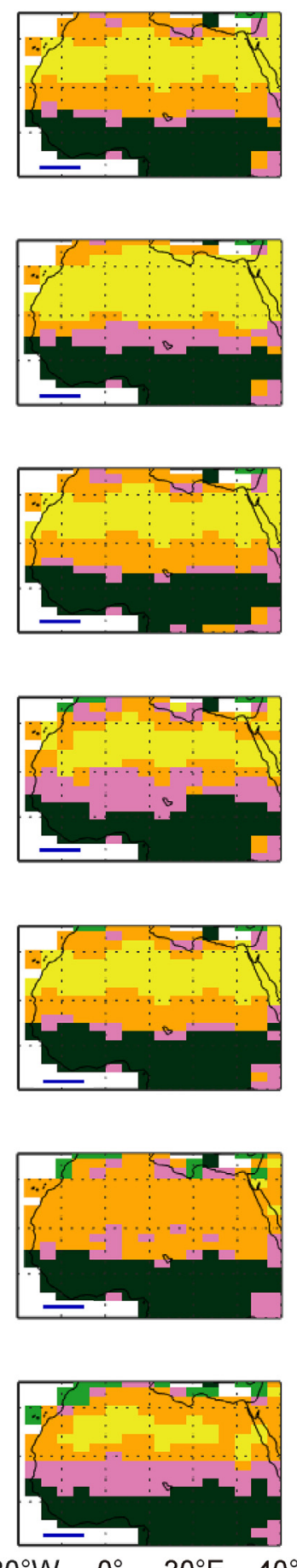

P400
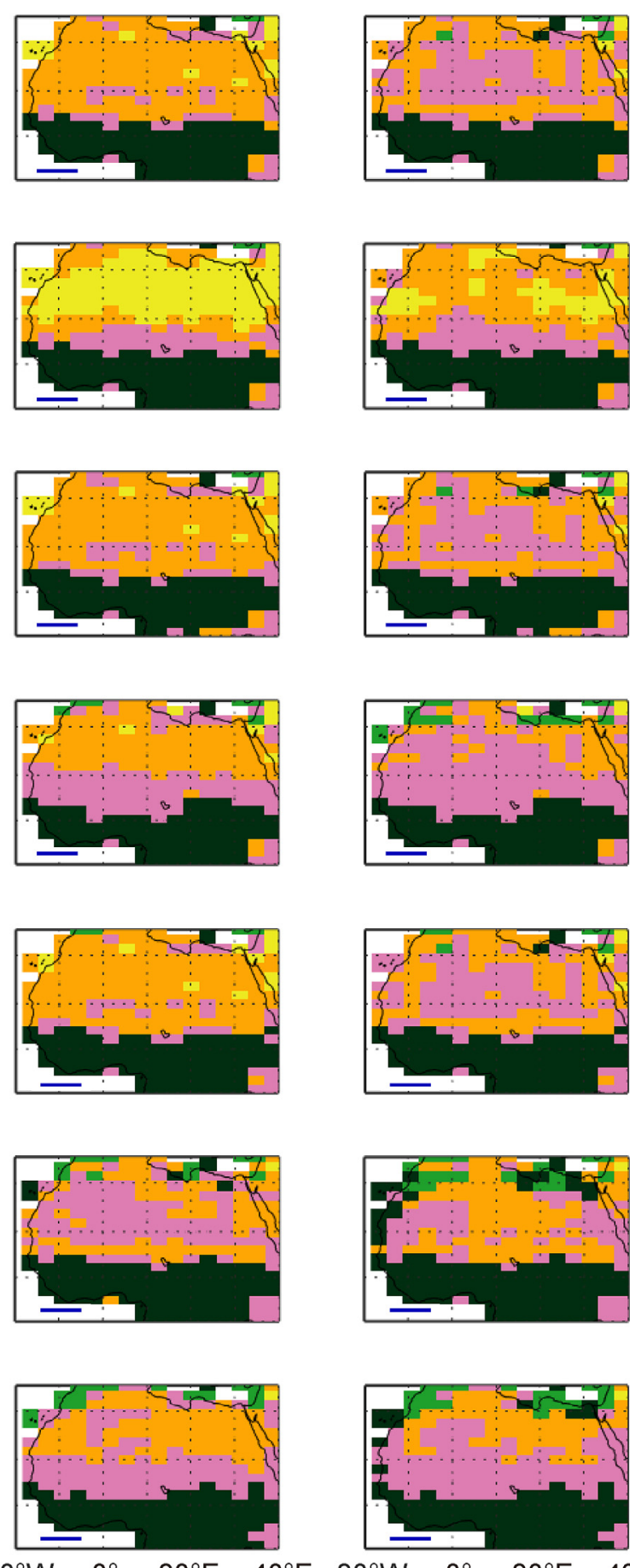

$20^{\circ} \mathrm{W} \quad 0^{\circ} \quad 20^{\circ} \mathrm{E} \quad 40^{\circ} \mathrm{E}$

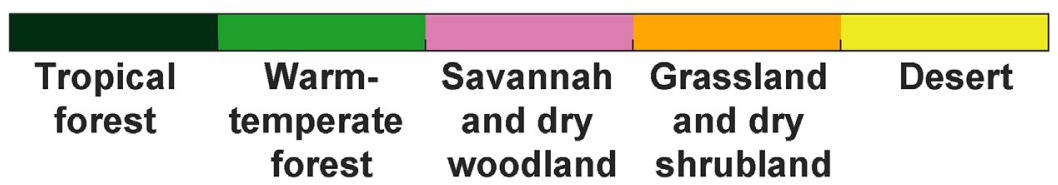

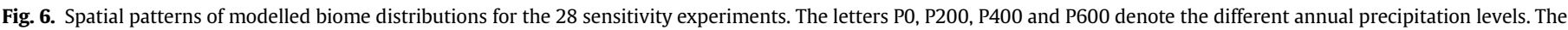

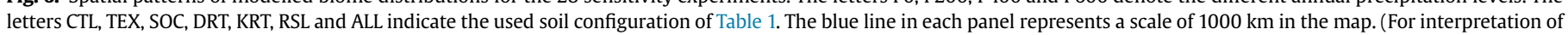
the references to color in this figure legend, the reader is referred to the Web version of this article.) 
region at $\sim 15^{\circ} \mathrm{N}$, compared with the reference simulations that has sandy soils in Sahara (Exp_CTL). In contrast, the increase of soil evaporative resistance (Rsoil) exerts a strong positive effect on vegetation in dry regions through transforming grassland to woodland. Similarly, the inclusion of dynamic root water uptake along the soil profile (Droot) replaces grassland by woodland in semi-humid region. But the SOC impact on soil water holding capacity (SOC effect) and the root enhanced water conductivity (Kroot) have limited impact on the modelled biome distribution.

Besides the impacts of precipitation and soil processes presented above, $\mathrm{CO}_{2}$ concentration and fire disturbance may also make a difference in the simulated vegetation distribution over the study area. We performed two additional simulations to isolate the effect of $\mathrm{CO}_{2}$ concentration and fire disturbance on biome distribution and tree cover (Fig. S2). Our results show limited changes of biome distribution and tree cover when using the $\mathrm{CO}_{2}$ concentration of the mid-Holocene level (264 ppm) instead of that of the preindustrial period (285 ppm). In contrast, switching-off fire disturbance in the model significantly increases tree cover by $40 \%$ at $\sim 16^{\circ} \mathrm{N}$ and leads to a northern migration of tropical forest by $\sim 4^{\circ}$ under P400_ALL simulation configurations. Consequently, we chose a more realistic configuration by fixing $\mathrm{CO}_{2}$ at $264 \mathrm{ppm}$ and activating fire disturbance in the mid-Holocene simulations for this study.

\subsection{Effect of individual soil process on carbon and water variables}

Soil processes influence vegetation pattern through modifying terrestrial water budgets and vegetation productivity. The NPP change is a sign of vegetation transformation in the model. The replacement of soil texture from sand to silt loam increases SM dramatically by $>100 \mathrm{~mm}(\sim 150 \%)$ (Fig. 7). However, with silt loam, NPP decreases in dry regions but increases in semi-humid regions.
As an actual mid-Holocene soil map does not exist, a range of soil textures are tested by reducing sand proportion from 90\% to 30\% (Fig. 2), which shows similar but gradual change in carbon and water variables (Fig. 8). Finer soil texture significantly increases field capacity (Fig. 9) and therefore leads to higher SM. But higher SM does not lead to higher NPP because much higher wilting point and lower $\mathrm{RH}$ in silt loam restrict vegetation growth. It explains why finer soil alone even leads to the desertification of dry Sahara regions (Fig. 6). Spatially, finer soil still shows positive effect in semi-humid regions at $\sim 15^{\circ} \mathrm{N}$, where $\mathrm{RH}$ shows no change, because water conductivity and drainage are reduced and SM is much higher (Fig. 8).

The inclusion of SOC effect on soil water holding capacity always increases SM in wet regions (Fig. 7). In the model, pure organic soil $\left(0.92 \mathrm{~m}^{3} / \mathrm{m}^{3}\right)$ has much larger saturated water content than sand $\left(0.43 \mathrm{~m}^{3} / \mathrm{m}^{3}\right)$ or silt loam $\left(0.45 \mathrm{~m}^{3} / \mathrm{m}^{3}\right)$, because of the higher porosity of soil organic matters (Table S1). Total soil water holding capacity is the fraction weighted average of mineral soil and organic soil. A higher SOC can give rise to positive feedbacks on vegetation through increasing SM. But the effect is mainly found in wet regions where SOC is sufficiently large to change the soil hydraulic properties.

The inclusion of dynamic root effect (Droot) shows some positive influence on vegetation, especially at $\sim 15^{\circ} \mathrm{N}$ (Fig. 7). For a selected pixel period after a rainfall event, vegetation transpires more water and results in higher NPP but lower SM when Droot is activated (Fig. S3). With Droot effect, the water stress for vegetation decreases so that vegetation uses soil water more efficiently even at a lower SM. As a result, the Droot effect decreases SM but increases NPP (Fig. 7).

The inclusion of root fracking induced increased infiltration (Kroot) increases drainage (Qd) at the expense of surface runoff (Qs) through modifying root enhanced water conductivity but (a) CTL

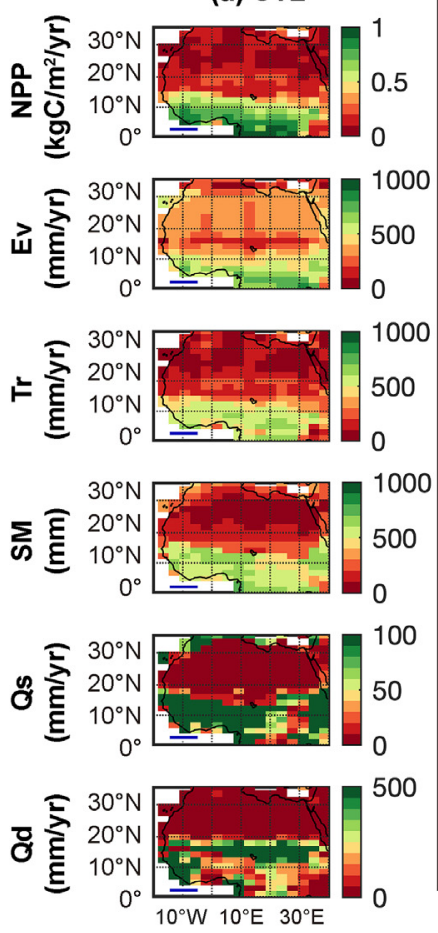

(b) Texture

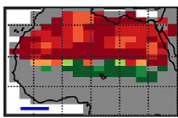

(c) $\mathrm{SOC}$
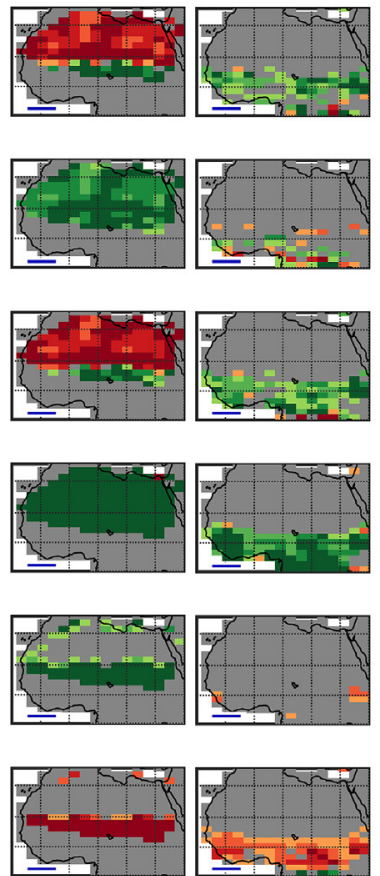

$10^{\circ} \mathrm{W} 10^{\circ} \mathrm{E} 30^{\circ} \mathrm{E} \quad 10^{\circ} \mathrm{W} 10^{\circ} \mathrm{E} 30^{\circ} \mathrm{E} 10^{\circ} \mathrm{W} 10^{\circ} \mathrm{E} 30^{\circ} \mathrm{E}$

(d) Droot
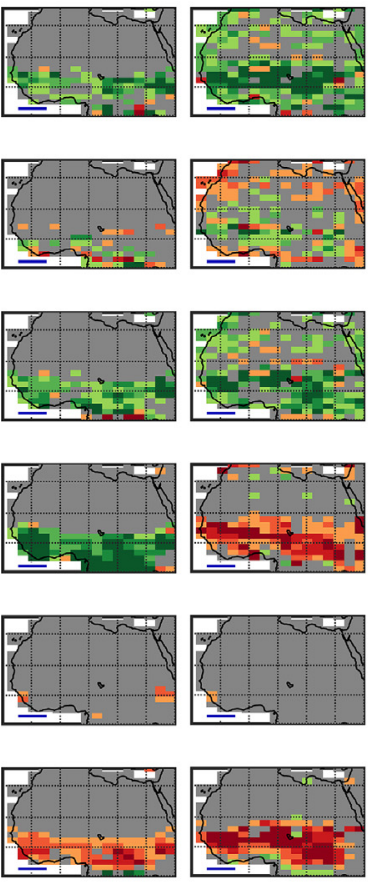

(e) Kroot

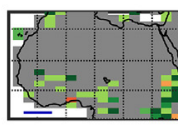

(f) Rsoil

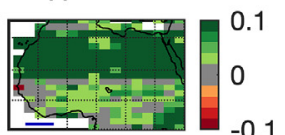

(g) All
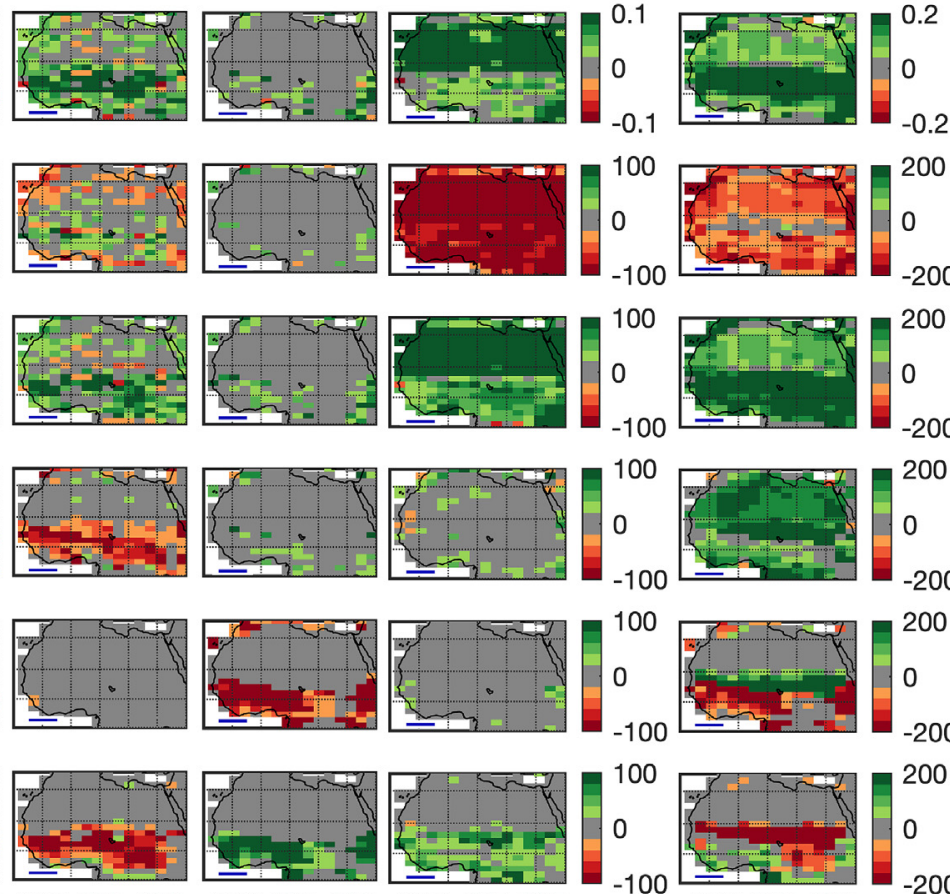

$10^{\circ} \mathrm{W} 10^{\circ} \mathrm{E} 30^{\circ} \mathrm{E} \quad 10^{\circ} \mathrm{W} 10^{\circ} \mathrm{E} 30^{\circ} \mathrm{E}$

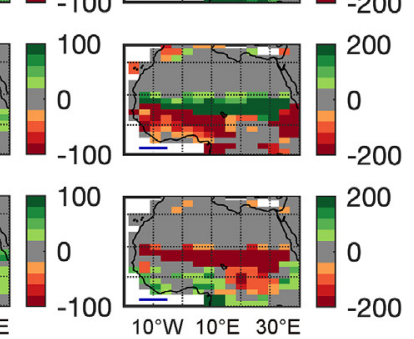

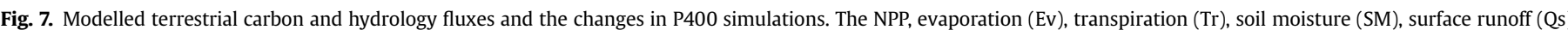

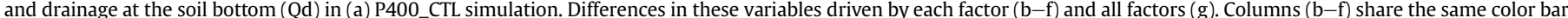

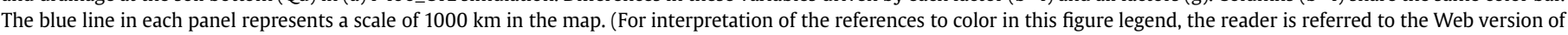
this article.) 
(a) Sand
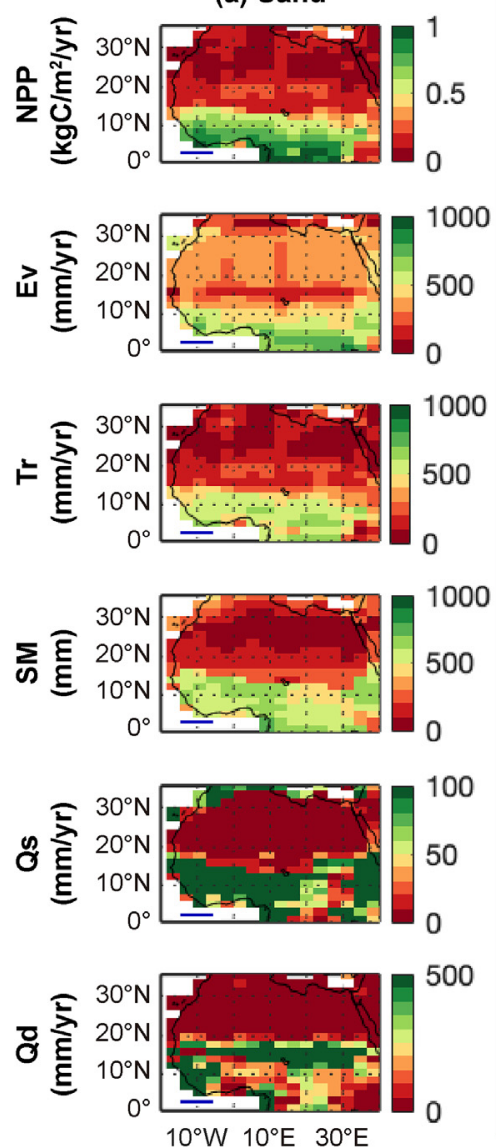

(b) LSa - Sand

(c) SaL - Sand

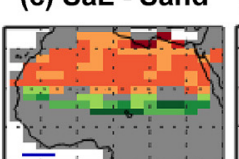

(d) SaCL - Sand
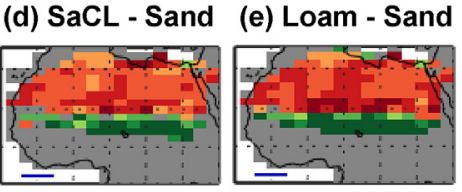

(f) SiL - Sand
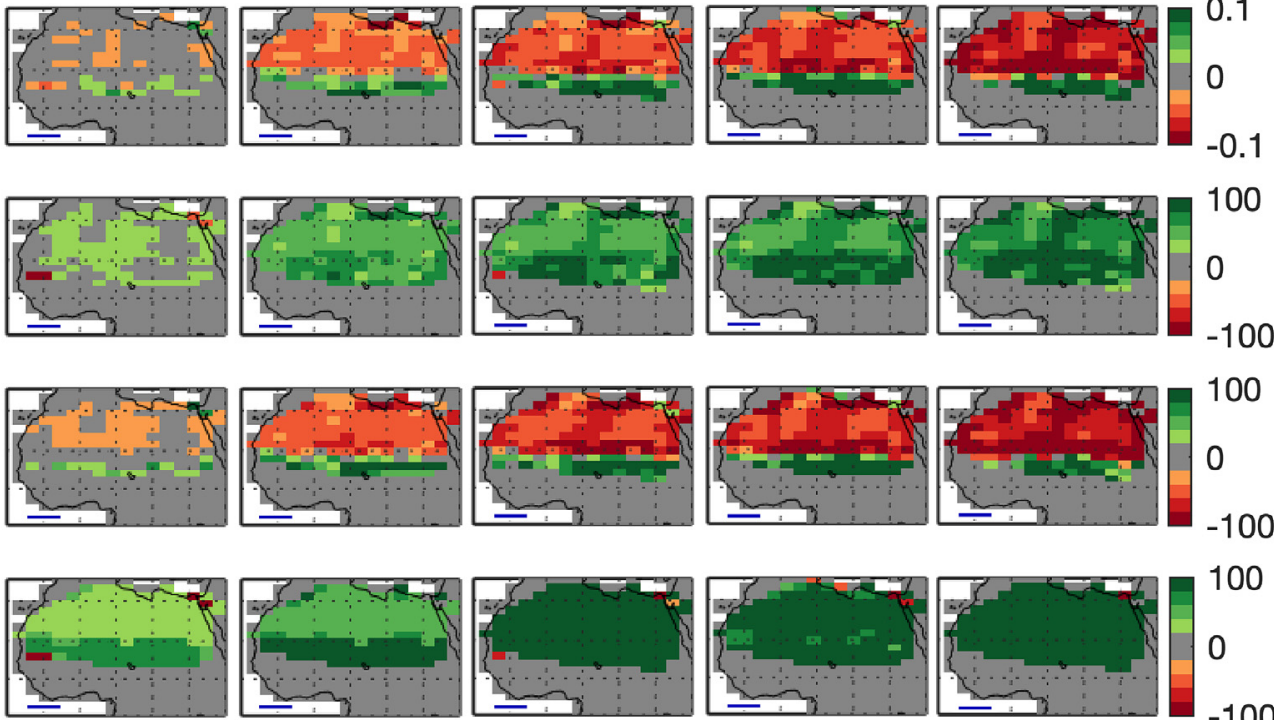

100
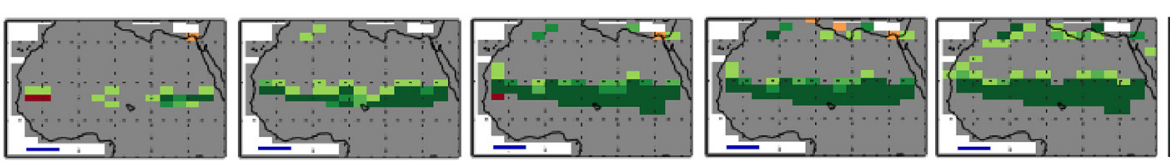

$-100$

100
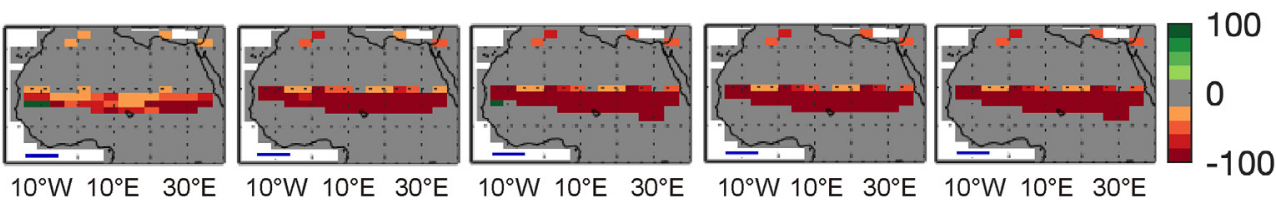

$10^{\circ} \mathrm{W} 10^{\circ} \mathrm{E} \quad 30^{\circ} \mathrm{E} \quad 10^{\circ} \mathrm{W} 10^{\circ} \mathrm{E} \quad 30^{\circ} \mathrm{E}$

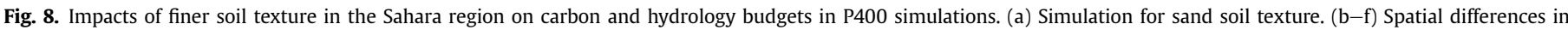

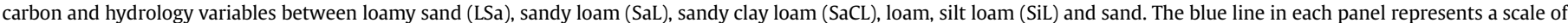
$1000 \mathrm{~km}$ in the map. (For interpretation of the references to color in this figure legend, the reader is referred to the Web version of this article.)

exerts limited effect on NPP (Fig. 7 and S3). The saturated hydraulic conductivity (Ks) is determined by soil texture (Ks_ref) and roots (Kroot) in the model. Plant root fracking does not have a large impact on water infiltration in the model because Ks in sandy soil is already very high. Realizing this interaction between Kroot and soil texture, we found that Kroot effect leads to prominent increases in NPP in semi-arid region at $\sim 20^{\circ} \mathrm{N}$ if soil texture is prescribed as silt loam $($ Ks_ref $=1060.8 \mathrm{~mm} / \mathrm{d})$ rather than sand (Ks_ref $=7128 \mathrm{~mm} /$ d) (Fig. S5; Table S1).

The increase of soil evaporative resistance (Rsoil) significantly reduces evaporation by $>100 \mathrm{~mm} / \mathrm{yr}(\sim 50 \%)$ and consequently increases NPP by $>0.1 \mathrm{kgC} / \mathrm{m}^{2} / \mathrm{yr}(\sim 150 \%)$ in dry regions. This recalibrated partition of evapotranspiration shows remarkable positive impact on NPP especially in dry regions. The increased Rsoil has the highest positive contribution to vegetation in the Sahara among the studied five factors. In summary, the relative importance of each factor contrasts between different climate conditions because their different roles in changing soil water hydraulic properties or water stress for vegetation. More detailed explanations and equations for the role of each process in the model is given in Text S1.

\section{Discussion}

\subsection{Importance of soil properties for simulating vegetation}

Although many attempts have been made to estimate precipitation in the mid-Holocene Sahara, there are still many uncertainties (Harrison et al., 2015; Hopcroft et al., 2017; Tierney et al., 2017). The importance of soil texture was previously shown with the LPJ_GUESS DGVM (Lund-Potsdam-Jena Dynamic Global Vegetation Model) by Lu et al. (2018), which quantified the influence of soil texture in the mid-Holocene Sahara simulations but did not address other soil factors. Here, the impacts of five soil processes are examined with an inverse modeling framework to determine the MAP required for the ORCHIDEE-MICT land surface model to produce a vegetation distribution consistent with paleoreconstructions. Our result suggests that $\sim 400 \mathrm{~mm} / \mathrm{yr}$ precipitation is enough for our model to reproduce vegetation extension after considering all the soil factors. This precipitation level is higher than previous estimate of $\sim 250 \mathrm{~mm} / \mathrm{yr}$ using a climate model by Egerer et al. (2018), in which there is still large desert in the mid-Holocene Sahara inconsistent with records. Our estimate is more comparable to previous studies through EC-Earth climate model (Pausata et al., 2016) and pollen-based reconstructions (Bartlein et al., 2010; Peyron et al., 2006; Wu et al., 2007), which suggested an additional rainfall of $\sim 350 \mathrm{~mm} / \mathrm{yr}$ in the midHolocene Sahara (Fig. 1). There are uncertainties in some pollenbased estimation of rainfall from simple vegetation models like BIOME4 (Coupled bio-geography and bio-geochemistry model), in which many important processes are not explicitly formulated. If only taking a plausible change of soil texture from sand to silt loam into consideration, ORCHIDE-MICT model would require more than $600 \mathrm{~mm} / \mathrm{yr}$ to reproduce the observed GS (Fig. 6), similar to the 

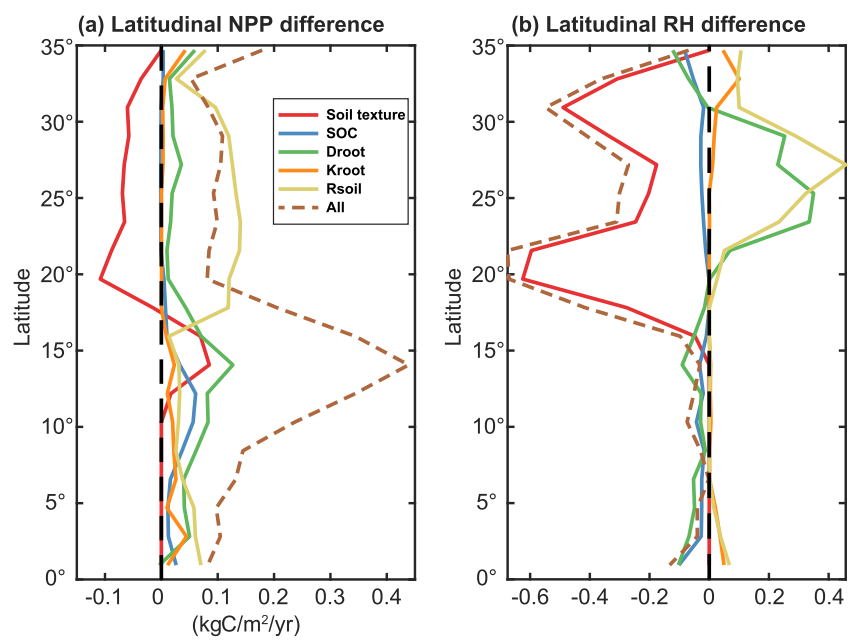

(c) Latitudinal $\theta \mathrm{c}$ difference
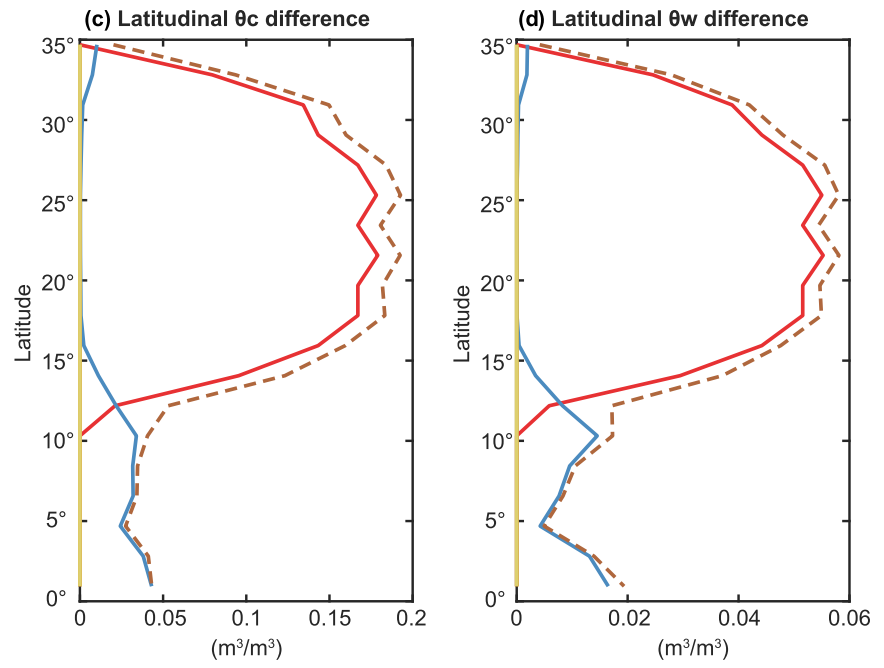

Fig. 9. Latitudinal differences in (a) NPP, (b) soil relative humidity (RH), (c) field capacity $(\theta c)$ and $(d)$ wilting point $(\theta w)$ for P400 simulations. The curves denote the differences between sensitivity experiments and the control simulation in P400 forcing (P400_CTL).

precipitation reconstruction of $500-800 \mathrm{~mm} / \mathrm{yr}$ by other land surface models (Hopcroft et al., 2017). It highlights the positive feedbacks of soil factors on sustaining GS vegetation under a lower precipitation threshold. We propose that future precipitation reconstructions based on vegetation models should carefully take soil feedbacks into consideration.

Soil moisture availability is a major constraint of productivity rate in most biomes, especially in dry regions (Chen et al., 2019b; Stocker et al., 2019). Each soil process considered in this study exerts feedbacks on vegetation through modifying soil hydraulic properties or soil stress for vegetation. Compared with present-day Sahara, a loamier soil texture at 6 ka could be deduced from sediments records (Kropelin et al., 2008; Palchan and Torfstein, 2019; Quade et al., 2018) and was adopted by some model studies (Levis et al., 2004; Lu et al., 2018). Factorial simulations from Lu et al. (2018) suggested that loamier soil during the GS period induces substantial extension of high vegetation between $15^{\circ} \mathrm{N}$ and $20^{\circ} \mathrm{N}$. This is consistent with our result that finer soil is favorable to savannah coverage and NPP in semi-humid regions (Figs. 6 and 7). On the contrary, in dry Sahara, we found that a higher wilting point with loamy soil results in a lower RH and therefore decreases NPP (Fig. 9).
Among the studied five soil factors, the increase of soil evaporative resistance (Rsoil) plays the most important role in increasing vegetation cover in the mid-Holocene Sahara region. The importance of litter in effectively reducing soil evaporation in vegetated dry region has been revealed by many field observations (Magliano et al., 2017; Xiong et al., 2019). Litter manipulation experiments in a dry grassland in China showed that SM and biomass decreased because of the removal of plant litter (Xiong et al., 2019). Previous attempts have been made to reduce simulated evaporation and recalibrate evapotranspiration partition in land surface models, like the CLM (Community Land Model) (Oleson et al., 2008) and The CABLE (CSIRO Atmosphere Biosphere Land Exchange Model) (Decker et al., 2017). In order to include this effect for modeling the climate impact of no tilled crop residues in Europe, Davin et al. (2014) increased soil resistance to empirically represent the resistance to soil evaporation associated with the residue mulch. Therefore, we added a soil resistance to reduce bare soil evaporation, similar to Oleson et al. (2008), to mimic the maintenance of SM because of vegetation and litterfall. We used a simulation PI385 to evaluate the performance to partition evapotranspiration. The ratio of evaporation to total terrestrial evapotranspiration (Ev/ET) in the vegetated area in North Africa from PI385 simulation is $0.49 \pm 0.02$ (Fig. S6), which is still overestimated like most Coupled Model Intercomparison Project Phase 5 (CMIP5) Earth system models $(0.59 \pm 0.11)$, compared to a recent global estimate of $0.38 \pm 0.06$ (Lian et al., 2018). Therefore, it is important to incorporate the plant litter effect on evaporation in order to better simulate vegetation dynamics during the GS period.

\subsection{Implications of improved vegetation modeling}

The mid-Holocene green Sahara enigma is a window of opportunity for models to identify interactions and feedbacks between climate and land processes. According to our simulations, the midHolocene GS ( 64.3 PgC) sustains ten times as much carbon as in PI $(\sim 6.8 \mathrm{PgC})$ in soil, litter and vegetation carbon pools between $15^{\circ} \mathrm{N}$ and $32^{\circ} \mathrm{N}$ (Table 2). It means the desertification of the Sahara released considerable carbon $(\sim 58 \mathrm{PgC})$ from terrestrial carbon pools. Our value is twice as much as an early estimate of $\sim 30 \mathrm{PgC}$ loss based on a simple carbon cycle model (Indermühle et al., 1999). Compared with terrestrial carbon budget estimate between 7-3 ka by Stocker et al. (2017), a carbon loss of $~ 58$ PgC equals to 32\% of terrestrial non-peatland carbon source after the mid-Holocene. The termination of the mid-Holocene GS thus was associated with a substantial carbon transfer from land surface to atmosphere through decomposition (Qiu et al., 2020) or to other regions because of aeolian processes (Yang et al., 2008). The released carbon to atmosphere may have an impact on climate.

The important feedbacks of Saharan vegetation cover and dust reduction on precipitation has been recognized recently (Messori et al., 2018; Sun et al., 2019). Changes in land cover can influence not only local climate (Groner et al., 2018) but also nonlocal land monsoon precipitation (Sun et al., 2019). Nevertheless, the importance of soil processes on vegetation and climate has not been revealed. Our analyses provide an insight in the soil-vegetation interactions, which may play a role in water recycling in the mid-

Table 2

Simulated carbon $(\mathrm{PgC})$ in vegetation, soil and litter pools in $\mathrm{PI}$ and $\mathrm{MH}$ (i.e. P400_ALL) simulations in the Sahara region between $15^{\circ} \mathrm{N}$ and $32^{\circ} \mathrm{N}$. Notice 1 $\mathrm{PgC}=10^{15} \mathrm{gC}$.

\begin{tabular}{lllll}
\hline Carbon pool & Vegetation & Soil & Litter & Sum \\
\hline PI & 0.5 & 5.7 & 0.5 & 6.8 \\
MH & 4.6 & 55.0 & 4.7 & 64.3 \\
\hline
\end{tabular}


Holocene North Africa. Thus, we propose to further explore the mid-Holocene precipitation with coupled land-atmosphere models after considering the soil processes explored in this study. In addition, it is worth to map paleolake and wetland distribution since water redistribution between upland and lowland influences both vegetation and climate (Tian et al., 2017; Zhang et al., 2019). And improved climate and land surface reconstructions of GS periods may have implications for the migration and evolution of hominins (Drake et al., 2011; Larrasoana et al., 2013).

\subsection{Limitations of the study}

In general, the results demonstrate different feedbacks of soil factors on vegetation. A few limitations in this work should be considered. Firstly, our estimate of annual precipitation is a regional average and does not provide insights on spatial details. Evidence from leaf wax isotopes in marine sediments indicates a much greater rainfall of $1280 \mathrm{~mm} / \mathrm{yr}$ at $31^{\circ} \mathrm{N}$ in the coastal region of north Africa (Tierney et al., 2017), which is captured by our result and most Earth System Models. And there is still uncertainty on whether the vegetation coverage was more or less continuous or confined to regions with local water availability (i.e. rivers, wetlands and fans). Secondly, we calculated a soil resistance to prevent bare soil evaporation, but it is dependent on SM in litter zone like many land surface models (Decker et al., 2017; Sellers et al., 1992). A more physically based treatment of this soil resistance as a function of litter content is favorable in future studies. Thirdly, we investigated lots of soil texture and chose silt loam as a representative because it dominates present-day Sahel region an analog to the mid-Holocene Sahara. However, a robust map would be better for quantitative analyses of carbon and hydrology budgets. Finally, further attempts should be made to characterize precipitation seasonality more than MAP, because rainfall timing can influence competition between woody and herbaceous according to field measurement (Brandt et al., 2019). However, it may rely on highresolution paleorecords and better climate models.

\section{Conclusions}

In this study, we examine feedbacks of soil processes on vegetation in the mid-Holocene North Africa by using the ORCHIDEEMICT land surface model. We separate five soil factors with seven sensitivity experiments for four precipitation scenarios. Results show that a reduced bare soil evaporation has the largest contribution to NPP and vegetation cover increase in the Sahara region. Compared with the control simulation, a finer soil texture increases SM significantly but decreases Saharan NPP. Other factors also play important roles in different conditions. SOC increases field capacity and soil moisture, hence has positive impacts on vegetation only in wet regions. A higher infiltration owing to the presence of root is beneficial to vegetation NPP and SM when interacting with finer soil type. Compound effect of these factors sustains the GS under a lower precipitation threshold $(\sim 400 \mathrm{~mm} / \mathrm{yr})$ than previous model estimates, highlighting the overall positive soil impacts on vegetation. Our result further reveals that the desertification of the Sahara from the mid-Holocene to pre-industrial period produced a large carbon source of $\sim 58 \mathrm{PgC}$. Finally, we propose that it is necessary to include soil feedbacks on vegetation and climate in further studies with regard to Earth System Models. Our work provides a possible analog of future vegetation transformation in North Africa.

\section{Author contribution statement}

Weizhe Chen: Conceptualization, Methodology, Formal analysis,
Investigation, Writing - original draft, Writing - review \& editing. Philippe Ciais: Conceptualization, Methodology, Writing - review \& editing, Supervision. Dan Zhu: Methodology, Software, Resources, Writing - review \& editing. Agnès Ducharne: Methodology, Software, Writing - review \& editing. Nicolas Viovy: Methodology, Resources, Writing - review \& editing. Chunjing Qiu: Software, Writing - review \& editing. Chunju Huang: Funding acquisition, Writing - review \& editing, Supervision.

\section{Declaration of competing interest}

The authors declare that they have no known competing financial interests or personal relationships that could have appeared to influence the work reported in this paper.

\section{Acknowledgments}

This work was supported by the National Natural Science Foundation of China (No. 41772029 and 41322013), the 111 Project (No. BP0820004), and Natural Science Foundation for Distinguished Young Scholars of Hubei Province of China (2016CFA051). W. Chen acknowledges support from the China Scholarship Council (No. 201806410044) for Ph.D. work at LSCE, France. P. Ciais acknewledges support from European Research Council Synergy project SyG-2013-610028 IMBALANCE-P and the ANR CLAND Convergence Institute. This work was performed using HPC resources from GENCI-TGCC (No. 2019-A0050106328). We acknowledge researchers who made their data available online, these including BIOME 6000 biome data (http://www.bridge.bris.ac.uk/ projects/BIOME_6000), and soil information from ISRIC (https:// www.isric.org/projects/africa-soil-profiles-database-afsp/ newgeneration). The simulation results are available at https:// data.mendeley.com/datasets/wrn97svy92/1 (https://doi.org/10. 17632/wrn97svy92.1).

\section{Appendix A. Supplementary data}

Supplementary data to this article can be found online at https://doi.org/10.1016/j.quascirev.2020.106389.

\section{References}

Adam, O., Schneider, T., Enzel, Y., Quade, J., 2019. Both differential and equatorial heating contributed to African monsoon variations during the mid-Holocene. Earth Planet Sci. Lett. 522, 20-29.

Aloysius, N.R., Sheffield, J., Saiers, J.E., Li, H., Wood, E.F., 2016. Evaluation of historical and future simulations of precipitation and temperature in central Africa from CMIP5 climate models. J. Geophys. Res.: Atmosphere 121 (1), 130-152.

Bartlein, P.J., Harrison, S.P., Brewer, S., Connor, S., Davis, B.A.S., Gajewski, K., Guiot, J. Harrison-Prentice, T.I., Henderson, A., Peyron, O., Prentice, I.C., Scholze, M., Seppä, H., Shuman, B., Sugita, S., Thompson, R.S., Viau, A.E., Williams, J., Wu, H. 2010. Pollen-based continental climate reconstructions at 6 and $21 \mathrm{ka}$ : a global synthesis. Clim. Dynam. 37 (3-4), 775-802.

Beer, C., Lucht, W., Gerten, D., Thonicke, K., Schmullius, C., 2007. Effects of soil freezing and thawing on vegetation carbon density in Siberia: a modeling analysis with the Lund-Potsdam-Jena Dynamic Global Vegetation Model (LPJDGVM). Global Biogeochem. Cycles 21 (1), GB1012.

Braconnot, P., Zhu, D., Marti, O., Servonnat, J., 2019. Strengths and challenges for transient Mid-to Late Holocene simulations with dynamical vegetation. Clim. Past 15 (3), 997-1024.

Brandt, M., Hiernaux, P., Rasmussen, K., Tucker, C.J., Wigneron, J.-P., Diouf, A.A., Herrmann, S.M., Zhang, W., Kergoat, L., Mbow, C., Abel, C., Auda, Y., Fensholt, R., 2019. Changes in rainfall distribution promote woody foliage production in the Sahel. Commun. Biol. 2 (1), 133.

Brierley, C., Manning, K., Maslin, M., 2018. Pastoralism may have delayed the end of the green Sahara. Nat. Commun. 9 (1), 4018.

Chen, W., Zhu, D., Ciais, P., Huang, C., Viovy, N., Kageyama, M., 2019a. Response of vegetation cover to $\mathrm{CO} 2$ and climate changes between Last Glacial Maximum and pre-industrial period in a dynamic global vegetation model. Quat. Sci. Rev. 218, 293-305

Chen, W., Zhu, D., Huang, C., Ciais, P., Yao, Y., Friedlingstein, P., Sitch, S., Haverd, V., Jain, A.K., Kato, E., Kautz, M., Lienert, S., Lombardozzi, D., Poulter, B., Tian, H., 
Vuichard, N., Walker, A.P., Zeng, N., 2019b. Negative extreme events in gross primary productivity and their drivers in China during the past three decades. Agric. For. Meteorol. 275, 47-58.

d'Orgeval, T., Polcher, J., Rosnay, P.d., 2008. Sensitivity of the West African hydrological cycle in ORCHIDEE to infiltration processes. Hydrol. Earth Syst. Sci. 12 (6), $1387-1401$.

Dallmeyer, A., Claussen, M., Brovkin, V., 2019. Harmonising plant functional type distributions for evaluating Earth System Models. Clim. Past 15, 335-366.

Davin, E.L., Seneviratne, S.I., Ciais, P., Olioso, A., Wang, T., 2014. Preferential cooling of hot extremes from cropland albedo management. Proc. Natl. Acad. Sci. U. S. A. 111 (27), 9757-9761.

Decker, M., Or, D., Pitman, A., Ukkola, A., 2017. New turbulent resistance parameterization for soil evaporation based on a pore-scale model: impact on surface fluxes in CABLE. J. Adv. Model. Earth Syst. 9 (1), 220-238.

Drake, N.A., Blench, R.M., Armitage, S.J., Bristow, C.S., White, K.H., 2011. Ancient watercourses and biogeography of the Sahara explain the peopling of the desert. Proc. Natl. Acad. Sci. U. S. A. 108 (2), 458-462.

Egerer, S., Claussen, M., Reick, C.H., 2018. Rapid increase in simulated North Atlantic dust deposition due to fast change of northwest African landscape during Holocene. Clim. Past 14, 1051-1066.

Elsig, J., Schmitt, J., Leuenberger, D., Schneider, R., Eyer, M., Leuenberger, M., Joos, F., Fischer, H., Stocker, T.F., 2009. Stable isotope constraints on Holocene carbon cycle changes from an Antarctic ice core. Nature 461 (7263), 507-510.

Gaetani, M., Messori, G., Zhang, Q., Flamant, C., Pausata, F.S.R., 2017. Understanding the mechanisms behind the northward extension of the west african monsoon during the mid-holocene. J. Clim. 30 (19), 7621-7642.

Groner, V.P., Raddatz, T., Reick, C.H., Claussen, M., 2018. Plant functional diversity affects climate-vegetation interaction. Biogeosciences 15 (7), 1947-1968.

Guimberteau, M., Zhu, D., Maignan, F., Huang, Y., Yue, C., Dantec-Nédélec, S., Ottlé, C., Jornet-Puig, A., Bastos, A., Laurent, P., Goll, D., Bowring, S., Chang, J., Guenet, B., Tifafi, M., Peng, S., Krinner, G., Ducharne, A., Wang, F., Wang, T., Wang, X., Wang, Y., Yin, Z., Lauerwald, R., Joetzjer, E., Qiu, C., Kim, H., Ciais, P., 2018. ORCHIDEE-MICT (v8.4.1), a land surface model for the high latitudes: model description and validation. Geosci. Model Dev. (GMD) 11 (1), 121-163.

Harrison, 2017. BIOME 6000 DB Classified Plotfile Version 1. University of Reading.

Harrison, S.P., Bartlein, P.J., Izumi, K., Li, G., Annan, J., Hargreaves, J., Braconnot, P., Kageyama, M., 2015. Evaluation of CMIP5 palaeo-simulations to improve climate projections. Nat. Clim. Change 5 (8), 735-743.

Hély, C., Lézine, A.M., contributors, A.P.D., 2014. Holocene changes in African vegetation: tradeoff between climate and water availability. Clim. Past 10 (2), 681-686.

Hengl, T., Mendes de Jesus, J., Heuvelink, G.B., Ruiperez Gonzalez, M., Kilibarda, M., Blagotic, A., Shangguan, W., Wright, M.N., Geng, X., Bauer-Marschallinger, B., Guevara, M.A., Vargas, R., MacMillan, R.A., Batjes, N.H., Leenaars, J.G., Ribeiro, E. Wheeler, I., Mantel, S., Kempen, B., 2017. SoilGrids250m: global gridded soil information based on machine learning. PloS One 12 (2), e0169748.

Hopcroft, P.O., Valdes, P.J., 2019. On the role of dust-climate feedbacks during the mid-holocene. Geophys. Res. Lett. 46 (3), 1612-1621.

Hopcroft, P.O., Valdes, P.J., Harper, A.B., Beerling, D.J., 2017. Multi vegetation model evaluation of the Green Sahara climate regime. Geophys. Res. Lett. 44 (13), 6804-6813.

Huxman, T.E., Smith, M.D., Fay, P.A., Knapp, A.K., Shaw, M.R., Loik, M.E., Smith, S.D., Tissue, D.T., Zak, J.C., Weltzin, J.F., Pockman, W.T., Sala, O.E., Haddad, B.M., Harte, J., Koch, G.W., Schwinning, S., Small, E.E., Williams, D.G., 2004. Convergence across biomes to a common rain-use efficiency. Nature 429 (6992), 651-654.

Indermühle, A., Stocker, T.F., Joos, F., Fischer, H., Smith, H.J., Wahlen, M., Deck, B., Mastroianni, D., Tschumi, J., Blunier, T., 1999. Holocene carbon-cycle dynamics based on CO2 trapped in ice at Taylor Dome, Antarctica. Nature 398 (6723), 121.

Kageyama, M., Braconnot, P., Bopp, L., Caubel, A., Foujols, M.-A., Guilyardi, E., Khodri, M., Lloyd, J., Lombard, F., Mariotti, V., 2013. Mid-holocene and last glacial maximum climate simulations with the IPSL model-Part I: comparing IPSL_CM5A to IPSL_CM4. Clim. Dynam. 40 (9-10), 2447-2468.

Kaptue, A.T., Prihodko, L., Hanan, N.P., 2015. On regreening and degradation in Sahelian watersheds. Proc. Natl. Acad. Sci. U. S. A. 112 (39), 12133-12138.

Krinner, G., Viovy, N., de Noblet-Ducoudré, N., Ogée, J., Polcher, J., Friedlingstein, P., Ciais, P., Sitch, S., Prentice, I.C., 2005. A dynamic global vegetation model for studies of the coupled atmosphere-biosphere system. Global Biogeochem. Cycles 19 (1).

Kropelin, S., Verschuren, D., Lezine, A.M., Eggermont, H., Cocquyt, C., Francus, P., Cazet, J.P., Fagot, M., Rumes, B., Russell, J.M., Darius, F., Conley, D.J., Schuster, M., von Suchodoletz, H., Engstrom, D.R., 2008. Climate-driven ecosystem succession in the Sahara: the past 6000 years. Science 320 (5877), 765-768.

Larrasoana, J.C., Roberts, A.P., Rohling, E.J., 2013. Dynamics of green Sahara periods and their role in hominin evolution. PloS One 8 (10), e76514.

Lawrence, D.M., Slater, A.G., 2007. Incorporating organic soil into a global climate model. Clim. Dynam. 30 (2-3), 145-160.

Levis, S., Bonan, G.B., Bonfils, C.I., 2004. Soil feedback drives the mid-Holocene North African monsoon northward in fully coupled CCSM2 simulations with a dynamic vegetation model. Clim. Dynam. 23 (7-8), 791-802.

Lézine, A.-M., Hély, C., Grenier, C., Braconnot, P., Krinner, G., 2011. Sahara and Sahel vulnerability to climate changes, lessons from Holocene hydrological data. Quat. Sci. Rev. 30 (21-22), 3001-3012.

Lian, X., Piao, S., Huntingford, C., Li, Y., Zeng, Z., Wang, X., Ciais, P., McVicar, T.R., Peng, S., Ottle, C., 2018. Partitioning global land evapotranspiration using CMIP5 models constrained by observations. Nat. Clim. Change 8 (7), 640.

Liu, Y., Piao, S., Gasser, T., Ciais, P., Yang, H., Wang, H., Keenan, T.F., Huang, M., Wan, S., Song, J., Wang, K., Janssens, I.A., Peñuelas, J., Huntingford, C., Wang, X., Altaf Arain, M., Fang, Y., Fisher, J.B., Huang, M., Huntzinger, D.N., Ito, A., Jain, A.K. Mao, J., Michalak, A.M., Peng, C., Poulter, B., Schwalm, C., Shi, X., Tian, H., Wei, Y., Zeng, N., Zhu, Q., Wang, T., 2019. Field-experiment constraints on the enhancement of the terrestrial carbon sink by CO2 fertilization. Nat. Geosci. 12 (10), 809-814.

Lu, Z., Miller, P.A., Zhang, Q., Wårlind, D., Nieradzik, L., Sjolte, J., Li, Q., Smith, B., 2019. Vegetation pattern and terrestrial carbon variation in past warm and cold climates. Geophys. Res. Lett. 46 (14), 8133-8143.

Lu, Z., Miller, P.A., Zhang, Q., Zhang, Q., Wårlind, D., Nieradzik, L., Sjolte, J., Smith, B., 2018. Dynamic vegetation simulations of the mid-holocene green Sahara. Geophys. Res. Lett. 45 (16), 8294-8303.

Lyford, F.P., Qashu, H.K., 1969. Infiltration rates as affected by desert vegetation. Water Resour. Res. 5 (6), 1373-1376.

Magliano, P.N., Giménez, R., Houspanossian, J., Páez, R.A., Nosetto, M.D. Fernández, R.J., Jobbágy, E.G., 2017. Litter is more effective than forest canopy reducing soil evaporation in Dry Chaco rangelands. Ecohydrology 10 (7), e1879.

McGee, D., deMenocal, P.B., Winckler, G., Stuut, J., Bradtmiller, L., 2013. The magnitude, timing and abruptness of changes in North African dust deposition over the last 20,000 yr. Earth Planet Sci. Lett. 371, 163-176.

Messori, G., Gaetani, M., Zhang, Q., Zhang, Q., Pausata, F.S.R., 2018. The water cycle of the mid-Holocene West African monsoon: the role of vegetation and dust emission changes. Int. J. Climatol. 39 (4), 1927-1939.

Michaletz, S.T., Cheng, D., Kerkhoff, A.J., Enquist, B.J., 2014. Convergence of terrestrial plant production across global climate gradients. Nature 512 (7512), 39-43.

Morris, P.J., Baird, A.J., Belyea, L.R., 2015. Bridging the gap between models and measurements of peat hydraulic conductivity. Water Resour. Res. 51 (7), 5353-5364.

O'Ishi, R., Abe-Ouchi, A., 2013. Influence of dynamic vegetation on climate change and terrestrial carbon storage in the Last Glacial Maximum. Clim. Past 9 (4), $1571-1587$.

Oleson, K., Niu, G.Y., Yang, Z.L., Lawrence, D., Thornton, P., Lawrence, P., Stöckli, R. Dickinson, R., Bonan, G., Levis, S., 2008. Improvements to the Community Land Model and their impact on the hydrological cycle. J. Geophys. Res.: Biogeosciences 113 (G1), G01021.

Palchan, D., Torfstein, A., 2019. A drop in Sahara dust fluxes records the northern limits of the African Humid Period. Nat. Commun. 10 (1), 3803.

Pausata, F.S.R., Messori, G., Zhang, Q., 2016. Impacts of dust reduction on the northward expansion of the African monsoon during the Green Sahara period. Earth Planet Sci. Lett. 434, 298-307.

Peyron, O., Jolly, D., Braconnot, P., Bonnefille, R., Guiot, J., Wirrmann, D., Chalié, F., 2006. Quantitative reconstructions of annual rainfall in Africa 6000 years ago: model-data comparison. J. Geophys. Res.: Atmosphere 111 (D24), D24110.

Prentice, C., Guiot, J., Huntley, B., Jolly, D., Cheddadi, R., 1996. Reconstructing biomes from palaeoecological data: a general method and its application to European pollen data at 0 and 6 ka. Clim. Dynam. 12 (3), 185-194.

Prentice, I.C., Harrison, S.P., Bartlein, P.J., 2011. Global vegetation and terrestrial carbon cycle changes after the last ice age. New Phytol. 189 (4), 988-998.

Pugh, T.A.M., Arneth, A., Kautz, M., Poulter, B., Smith, B., 2019. Important role of forest disturbances in the global biomass turnover and carbon sinks. Nat. Geosci. 12 (9), 730-735.

Qiu, C., Zhu, D., Ciais, P., Guenet, B., Peng, S., Xu, X., 2020. The role of northern peatlands in the global carbon cycle for the 21st century. Global Ecol. Biogeogr. 29 (5), 956-973.

Quade, J., Dente, E., Armon, M., Ben Dor, Y., Morin, E., Adam, O., Enzel, Y., 2018. Megalakes in the Sahara? A review. Quat. Res. 90 (2), 253-275.

Rachmayani, R., Prange, M., Schulz, M., 2015. North African vegetation-precipitation feedback in early and mid-Holocene climate simulations with CCSM3-DGVM. Clim. Past 11 (2), 175-185.

Sellers, P.J., Heiser, M.D., Hall, F.G., 1992. Relations between surface conductance and spectral vegetation indices at intermediate $(100 \mathrm{~m} 2$ to $15 \mathrm{~km} 2)$ length scales. J. Geophys. Res.: Atmosphere 97 (D17), 19033-19059.

Stocker, B.D., Yu, Z., Massa, C., Joos, F., 2017. Holocene peatland and ice-core data constraints on the timing and magnitude of $\mathrm{CO} 2$ emissions from past land use. Proc. Natl. Acad. Sci. U. S. A. 114 (7), 1492-1497.

Stocker, B.D., Zscheischler, J., Keenan, T.F., Prentice, I.C., Seneviratne, S.I., Peñuelas, J., 2019. Drought impacts on terrestrial primary production underestimated by satellite monitoring. Nat. Geosci. 12, 264-270.

Sun, W., Wang, B., Zhang, Q., Pausata, F.S.R., Chen, D., Lu, G., Yan, M., Ning, L., Liu, J., 2019. Northern hemisphere land monsoon precipitation increased by the green Sahara during middle Holocene. Geophys. Res. Lett. 46 (16), 9870-9879.

Tafasca, S., Ducharne, A., Valentin, C., 2019. Weak sensitivity of the terrestrial water budget to global soil texture maps in the ORCHIDEE land surface model. Hydrol. Earth Syst. Sci. Discuss. 2019, 1-20.

Thompson, A.J., Skinner, C.B., Poulsen, C.J., Zhu, J., 2019. Modulation of mid-holocene african rainfall by dust aerosol direct and indirect effects. Geophys. Res. Lett. 46 (7), 3917-3926.

Thonicke, K., Spessa, A., Prentice, I.C., Harrison, S.P., Dong, L., Carmona-Moreno, C., 2010. The influence of vegetation, fire spread and fire behaviour on biomass burning and trace gas emissions: results from a process-based model. Biogeosciences 7 (6), 1991-2011.

Tian, F., Cao, X., Dallmeyer, A., Zhao, Y., Ni, J., Herzschuh, U., 2017. Pollen-climate 
relationships in time ( $9 \mathrm{ka}, 6 \mathrm{ka}, 0 \mathrm{ka}$ ) and space (upland vs. lowland) in eastern continental Asia. Quat. Sci. Rev. 156, 1-11.

Tierney, J.E., Pausata, F.S., deMenocal, P.B., 2017. Rainfall regimes of the green Sahara. Sci. Adv. 3 (1), e1601503.

Van Genuchten, M.T., 1980. A closed-form equation for predicting the hydraulic conductivity of unsaturated soils 1 . Soil Sci. Soc. Am. J. 44 (5), 892-898.

Wei, F., Wang, S., Fu, B., Wang, L., Liu, Y.Y., Li, Y., 2019. African dryland ecosystem changes controlled by soil water. Land Degrad. Dev. 30 (13), 1564-1573.

Wei, Y., Liu, S., Huntzinger, D.N., Michalak, A.M., Viovy, N., Post, W.M., Schwalm, C.R Schaefer, K., Jacobson, A.R., Lu, C., Tian, H., Ricciuto, D.M., Cook, R.B., Mao, J., Shi, X., 2014. the North American carbon program multi-scale synthesis and terrestrial model Intercomparison Project - Part 2: environmental driver data. Geosci. Model Dev. (GMD) 7 (6), 2875-2893.

Wu, H., Guiot, J., Brewer, S., Guo, Z., 2007. Climatic changes in Eurasia and Africa at the last glacial maximum and mid-Holocene: reconstruction from pollen data using inverse vegetation modelling. Clim. Dynam. 29 (2-3), 211-229.

Xiong, Y., Yu, B., Bai, M., Zhang, X., Huang, G., Furman, A., 2019. Soil properties and plant growth response to litter in a prolonged enclosed grassland of loess plateau, China. J. Earth Sci. 30 (5), 1041-1048.

Yang, X., Zhu, B., Wang, X., Li, C., Zhou, Z., Chen, J., Wang, X., Yin, J., Lu, Y., 2008. Late
Quaternary environmental changes and organic carbon density in the Hunshandake Sandy Land, eastern Inner Mongolia, China. Global Planet. Change 61 $(1-2), 70-78$.

Yue, C., Ciais, P., Cadule, P., Thonicke, K., Archibald, S., Poulter, B., Hao, W.M., Hantson, S., Mouillot, F., Friedlingstein, P., Maignan, F., Viovy, N., 2014. Modelling the role of fires in the terrestrial carbon balance by incorporating SPITFIRE into the global vegetation model ORCHIDEE - Part 1: simulating historical global burned area and fire regimes. Geosci. Model Dev. (GMD) 7 (6), 2747-2767.

Zhang, Z., Arnault, J., Wagner, S., Laux, P., Kunstmann, H., 2019. Impact of lateral terrestrial water flow on land-atmosphere interactions in the heihe river basin in China: fully coupled modeling and precipitation recycling analysis. J. Geophys. Res.: Atmosphere 124 (15), 8401-8423.

Zhu, D., Ciais, P., Chang, J., Krinner, G., Peng, S., Viovy, N., Penuelas, J., Zimov, S., 2018. The large mean body size of mammalian herbivores explains the productivity paradox during the Last Glacial Maximum. Nat. Ecol. Evol. 2 (4), 640-649.

Zhu, D., Peng, S.S., Ciais, P., Viovy, N., Druel, A., Kageyama, M., Krinner, G., Peylin, P., Ottlé, C., Piao, S.L., Poulter, B., Schepaschenko, D., Shvidenko, A., 2015. Improving the dynamics of Northern Hemisphere high-latitude vegetation in the ORCHIDEE ecosystem model. Geosci. Model Dev. (GMD) 8 (7), 2263-2283. 